
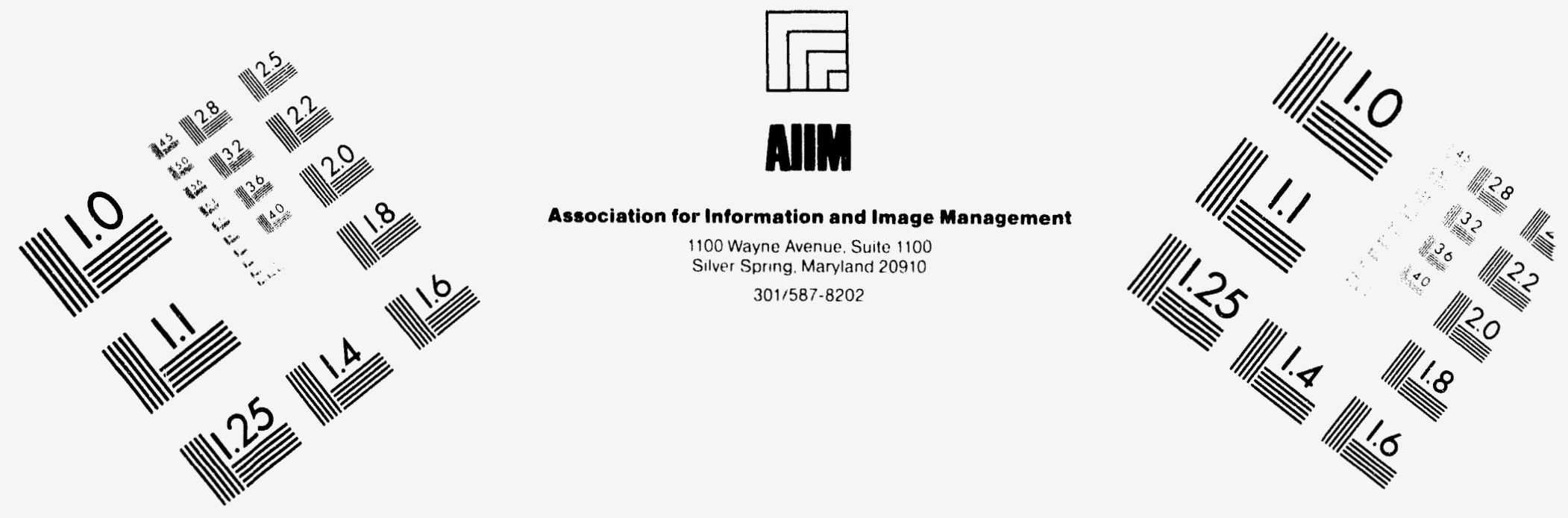

\title{
Centimeter
}

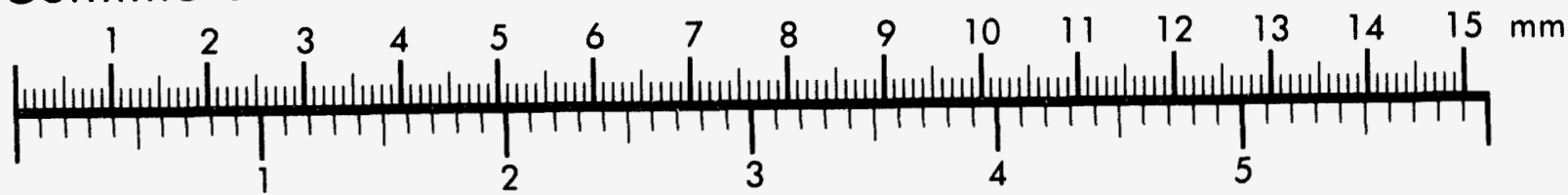
Inches
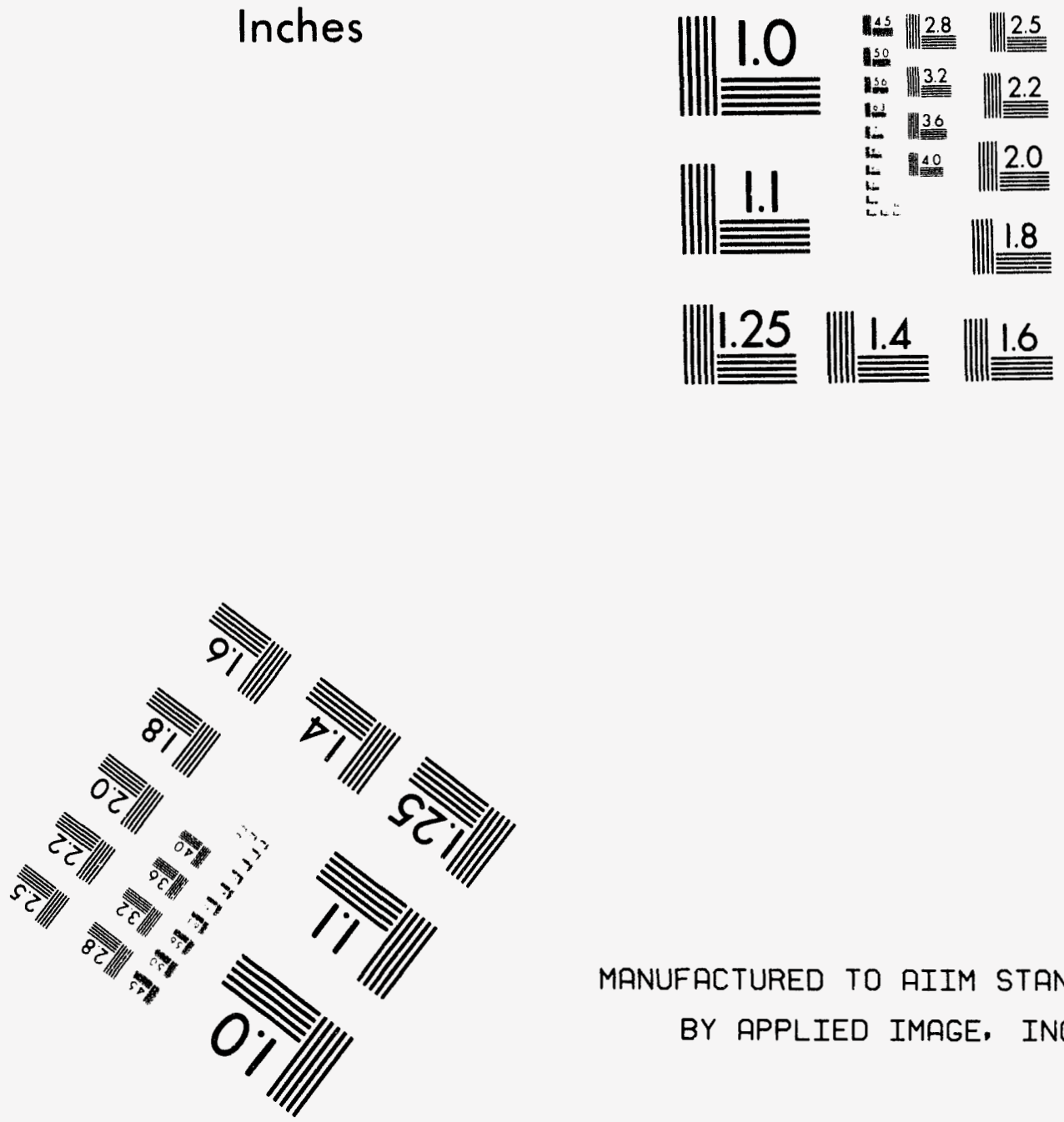

MANUFACTURED TO AIIM STANDARDS BY APPLIED IMAGE, INC.

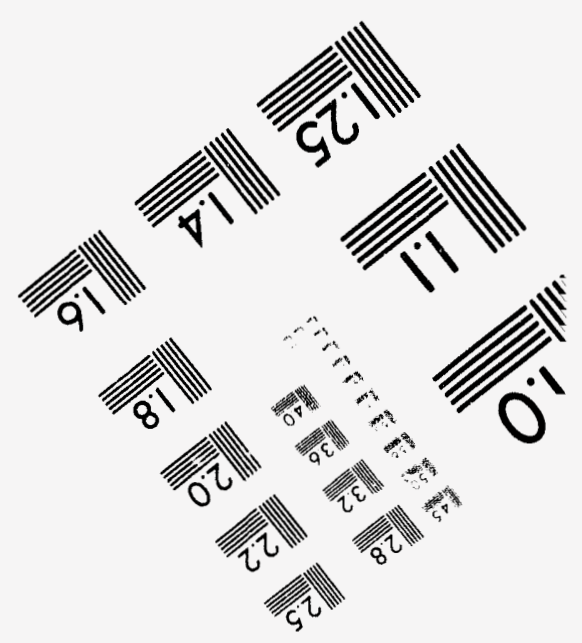



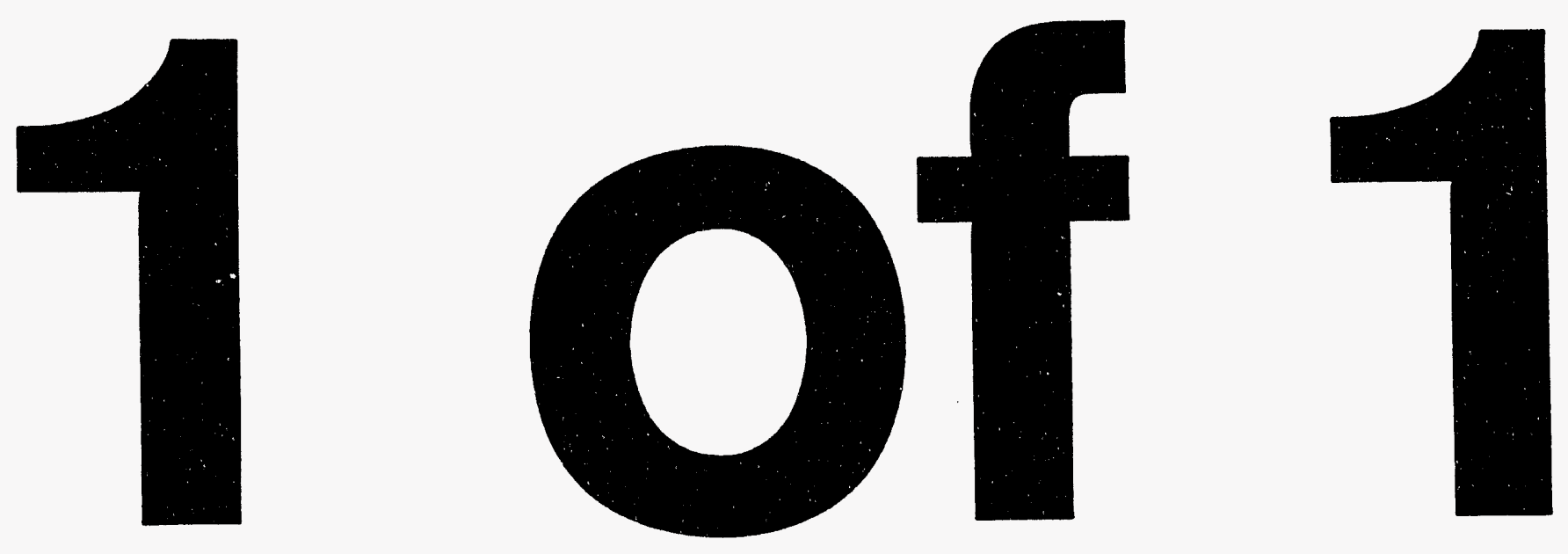


\title{
Site Scientific Mission Plan for the Southern Great Plains CART Site
}

\section{July-December 1994}

July 1994

\author{
Jeanne M. Schneider and Peter J. Lamb \\ Cooperative Institute for Mesoscale Meteorological Studies \\ The University of Oklahoma \\ Norman, Oklahoma 73019 \\ and \\ Douglas L. Sisterson \\ Environmental Research Division \\ Argonne National Laboratory \\ Argonne, Illinois 60439
}

Work supported by United States Department of Energy,

Office of Energy Research,

Office of Health and Environmental Research
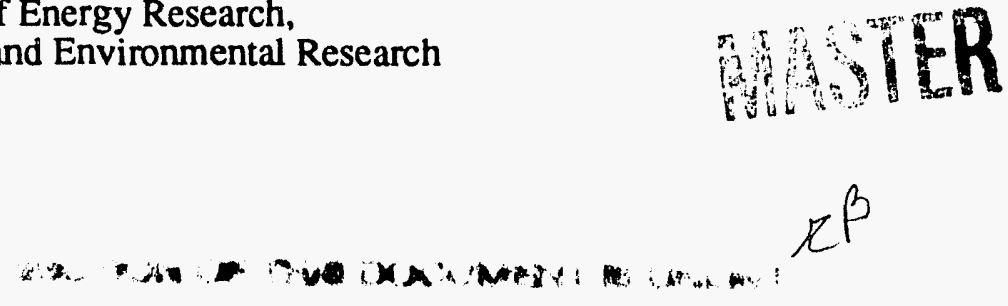


\section{CONTENTS}

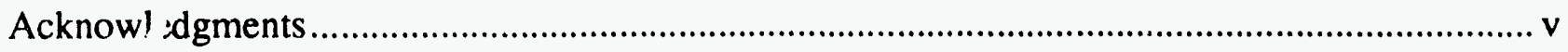

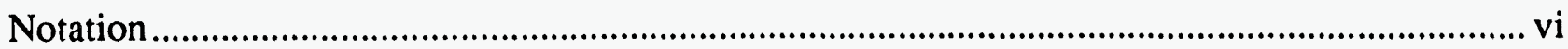

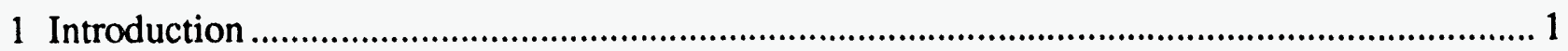

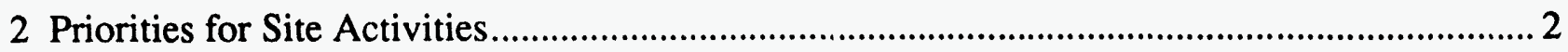

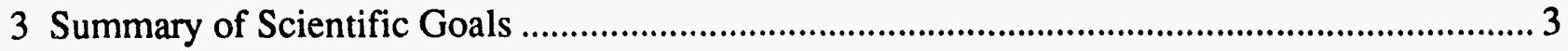

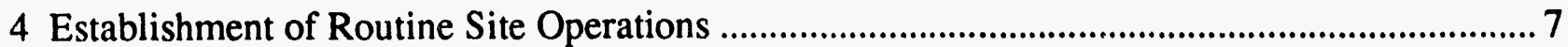

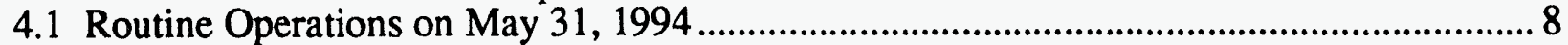

4.2 Site Development Activities .............................................................................................. 20

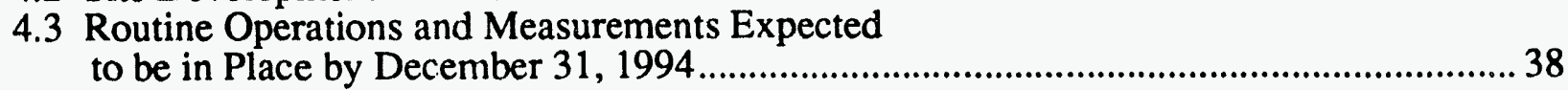

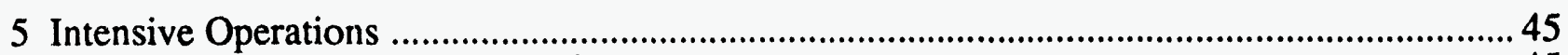

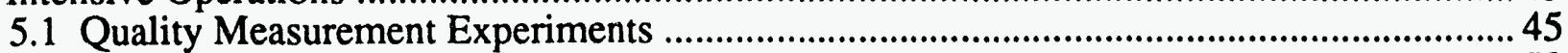

5.2 Supplement to Continuous Observations............................................................................. 50

5.3 Support for the Instrument Development Programs, Guest Instruments, and Campaigns ......................................................................................5 51

5.4 Campaign Planning .......................................................................................................... 51

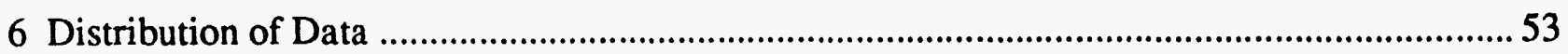

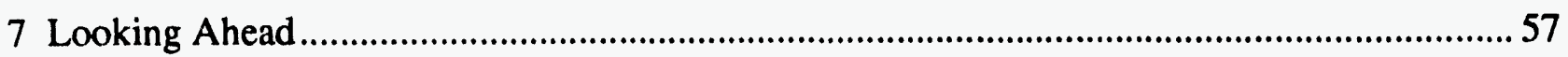

FIGURES

1 Overall View of the SGP CART Site

2 Site Development Activities to Establisn Routine Operations .................................................... 26

3 Site Development Activities to Install Central Facility ................................................................... 36 


\section{TABLES}

1 Instruments and Observational Systems in Place at the Central, Boundary, and Auxiliary Facilities on May 31, 1994

2 Instruments and Observational Systems in Place at the Extended Facilities on May 31, 1994

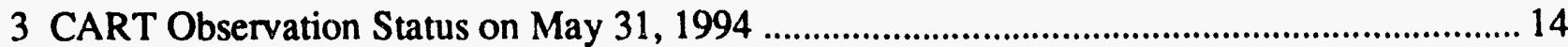

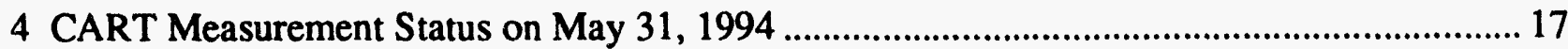

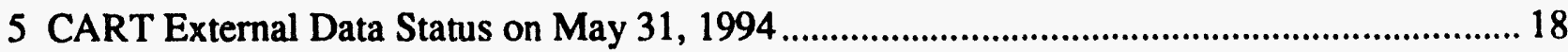

6 Observational Instruments and Systems Expected to be in Place at Central and Boundary Facilities by December 31, 1994 ...................................... 22

7 Observational Instruments and Systems Expected to be in Place at Extended Facilities, Apart from the Central Facility, by December 31, 1994 ...................... 24

8 Status of Instrument Acquisition and Deployment on May 31, 1994 ................................. 27

9 Status of Radiometric Calibration Facility on May 31, 1994 ............................................ 32

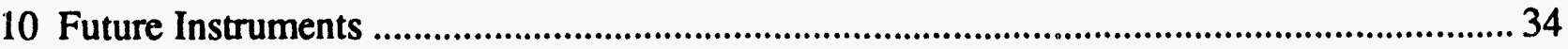

11 Rawinsonde Launch Schedule, July 1-December 31, 1994 .......................................... 39

12 CART Measurements Expected to be in Place by December 31, 1994 ............................... 40

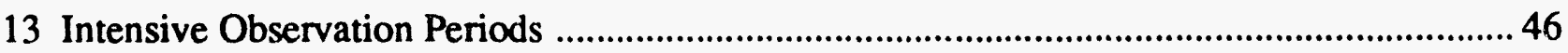

14 Collaborative Campaigns and Activities under Discussion ................................................ 52

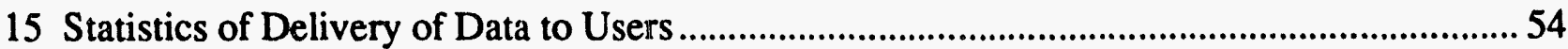




\section{ACKNOWLEDGMENTS}

This research was supported by the Atmospheric Radiation Measurement Program of the Atmospheric and Climate Research Division, Office of Health and Environmental Research, Office of Energy Research, U.S. Department of Energy, under contract PNL 144880-A-Q1 at the Cooperative Institute for Mesoscale Meteorological Studies, The University of Oklahoma (Schneider and Lamb), and under contract W-31-109-Eng-38 at Argonne National Laboratory (Sisterson). 


\section{NOTATION}

$\begin{array}{ll}\text { AER } & \text { Atmospheric and Environmental Research, Inc. } \\ \text { AERI } & \text { atmospherically emitted radiation interferometer } \\ \text { ARM } & \text { Atmospheric Radiation Measurement } \\ \text { BBSS } & \text { balloon-borne sounding system } \\ \text { BSRN } & \text { Broadband Solar Radiation Network } \\ \text { BOREAS } & \text { Boreal Ecosystems Atmosphere Study } \\ \text { CART } & \text { Cloud and Radiation Testbed } \\ \text { CASES } & \text { Cooperative Atmosphere-Surface Exchange Site } \\ \text { CCN } & \text { cloud condensation nuclei } \\ \text { CIMMS } & \text { Cooperative Institute for Mesoscale Meteorological Studies } \\ \text { CSU } & \text { Colorado State University } \\ \text { CU } & \text { Colorado University } \\ \text { DA } & \text { data assimilation } \\ \text { DMT } & \text { Data Management Team } \\ \text { DOA } & \text { Department of Agriculture } \\ \text { EBBR } & \text { energy balance Bowen ratio } \\ \text { EC } & \text { eddy correlation } \\ \text { EFCOS } & \text { extended facility code operations switch } \\ \text { EML } & \text { Environmental Measurements Laboratory } \\ \text { EOP } & \text { experiment operations plan } \\ \text { EST } & \text { Experiment Support Team } \\ \text { FDDA } & \text { four-dimensional data assimilation } \\ \text { FTP } & \text { File Transfer Protocol } \\ \text { GCIP } & \text { GEWEX Continental-Scale International Project } \\ \text { GCSS } & \text { GEWEX Cloud System Study } \\ \text { GEWEX } & \text { Global Energy and Water Cycle Experiment } \\ \text { GIST } & \text { GEWEX Integrated System Test } \\ \text { GMS } & \text { general measurement strategies } \\ \text { GMT } & \text { Greenwich Mean Time } \\ \text { GOES } & \text { geostationary orbiting Earth satellite } \\ \text { GPS } & \text { global positioning system } \\ \text { GSFC } & \text { Goddard Space Flight Center } \\ \text { GVaP } & \text { GEWEX Water Vapor Project } \\ \text { HD } & \text { hierarchical diagnosis } \\ \text { IDP } & \text { Instrument Development Program } \\ \text { IOP } & \text { Intensive Observation Period } \\ \text { IR } & \text { infrared } \\ \text { IRF } & \text { instantaneous radiative flux } \\ \text { ISLSCP } & \text { International Satellite Land-Surface Climatology Project } \\ \text { ISS } & \text { integrated sounding system } \\ \text { IT } & \text { Instrument Team } \\ \text { LBLRTM } & \text { line-by-line radiative transfer model } \\ \text { MFRSR } & \text { multifilter rotating shadowband radiometer } \\ & \end{array}$




\section{NOTATION (Cont.)}

\begin{tabular}{|c|c|}
\hline MWR & microwave radiometer \\
\hline NASA & National Aeronautics and Space Administration \\
\hline NCAR & National Center for Atmospheric Research \\
\hline NCSU & North Carolina State University \\
\hline NGM & Nested Grid Model \\
\hline NIP & normal-incidence pyrheliometer \\
\hline NIST & National Institute of Standards and Technology \\
\hline NOAA & National Oceanic and Atmospheric Administration \\
\hline NREL & National Renewable Energy Laboratory \\
\hline NSSL & National Severe Storms Laboratory \\
\hline NWS & National Weather Service \\
\hline OU & Oklahoma University \\
\hline PBL & planetary boundary layer \\
\hline PNL & Pacific Northwest Laboratory \\
\hline PSU & Pennsylvania State University \\
\hline QME & quality measurement experiment \\
\hline RASS & radio acoustic sounding system \\
\hline SCM & single-column model \\
\hline SDS & site data system \\
\hline SGP & Southern Great Plains \\
\hline SIROS & solar and infrared radiation observing station \\
\hline SMOS & surface meteorological observation station \\
\hline SNL & Sandia National Laboratories \\
\hline SORTI & solar radiance transmission interferometer \\
\hline SST & Site Scientist Team \\
\hline TOA & top of atmosphere \\
\hline UAV & unmanned aerospace vehicle \\
\hline UM & University of Massachussetts \\
\hline UNAVCO & University NAVSTAR Consortium \\
\hline UPS & uninterruptable power supply \\
\hline USAF & U.S. Air Force \\
\hline UTC & universal time coordinates \\
\hline UU & University of Utah \\
\hline UV & ultraviolet \\
\hline UW & University of Wisconsin \\
\hline VISSR & visible/infrared spin-scan radiometer \\
\hline VORTEX & Verification of the Origins of Rotation in Tornadoes Experiment \\
\hline WPL & Wave Propagation Laboratory \\
\hline WSI & whole-sky imager \\
\hline WVMR & water vapor mixing ratio \\
\hline 2-D & two dimensional \\
\hline 3-D & three dimensional \\
\hline
\end{tabular}




\section{SITE SCIENTIFIC MISSION PLAN \\ FOR THE SOUTHERN GREAT PLAINS CART SITE \\ JULY-DECEMBER 1994}

\section{INTRODUCTION}

The Southern Great Plains (SGP) Cloud and Radiation Testbed (CART) site is designed to help satisfy the data needs of the Atmospheric Radiation Measurement (ARM) Program Science Team. This document defines the scientific priorities for site activities during the six months beginning on July 1, 1994, and also looks forward in lesser detail to subsequent sixmonth periods. The primary purpose of this Site Scientific Mission Plan is to provide guidance for the development of plans for site operations. It also provides information on current plans to the ARM Functional Teams (Management Team, Experiment Support Team, Operations Team, Data Management Team, Instrument Team, and Campaign Team), and it serves to disseminate the plans more generally within the ARM Program and among the Science Team. This document includes a description of the site's operational status and the primary envisaged site activities, together with information concerning approved anit proposed Intensive Observation Periods. Amendments will be prepared and distributed whenever the content changes by more than $30 \%$ within a six-month period. The primary users of this document are the site operator, the site scientist, the Science Team through the ARM Program Science Director, the ARM Program Experiment Center, and the aforementioned ARM Program Functional Teams. This plan is a living document that will be updated and reissued every six months as the observational facilities are developed, tested, and augmented and as priorities are adjusted in response to developments in scientific planning and understanding. 


\section{PRIORITIES FOR SITE ACTIVITIES}

In descending order, we rank the priorities site activities for July-December 1994 as follows:

1. Establish routine site operations.

2. Support all data quality assurance efforts, including implementation of quality measurement experiments.

3. Plan and implement key Intensive Observation Periods.

4. Support the Instrument Development Program.

5. Plan and implement campaigns.

Within this ranking, the differences in relative importance between adjacent items are not large, but the top priority is clearly routine operations. The categorization is also somewhat artificial, because many site activities are multipurpose. For example, Intensive Observation Period (IOP) activities can simultaneously support Science Team, Instrument Development Program (IDP), and campaign requirements. Even so, this ranking reflects our scientific assessment of the activities that should receive the most support during this period. The SGP site and the supporting structures within the ARM Program are still being consolidated. Progress to date has been significant, but substantial work remains to bring this facility and the data stream to full maturity. At the central facility, the calibration and aerosol trailers await development; a number of instruments need to be installed, modified, or tested; and the site data system has yet to become operational. The suite of boundary and extended facilities needs to be completed, and decisions must be made about the auxiliary facilities. Methodologies for developing scientifically sound and cost-effective plans for IOPs and campaigns are being developed and tested. Data quality assurance efforts are underway, but in their infancy. The IOPs will focus on providing critical data on an episodic basis to the Science Team, as well as field support for instrument development and testing and collaborative campaigns. Simply stated, the primary scientific goal for this period is the same as the goal for the last six months: translation of site implementation activities into routine data streams of known quality for as many parameters as possible. 


\section{SUMMARY OF SCIENTIFIC GOALS}

The primary goal of the SGP CART site activities is to produce data adequate to support significant research addressing the ARM Program objectives. These overall objectives, as paraphrased from the ARM Program Plan, are the following:

- To describe the radiative energy flux profile of the clear and cloudy atmosphere

- To understand the processes determining the flux profile

- To parameterize the processes determining the flux profile for incorporation into general circulation models

To address these scientific issues, an empirical data set must be developed that includes observations of the evolution of the radiative state of the column of air over the entire $350-\mathrm{km} \mathrm{x}$ 400-km SGP CART site, as well as the processes that control that radiative state, in sufficient detail and quality to support the investigations proposed by the ARM Science Team. This data set includes measurements of radiative fluxes (solar and infrared) and the advective and surface fluxes of moisture, heat, and momentum occurring within the column and across its boundaries. Other entities to be described are cloud types, composition, and distribution (depth, fractional coverage, and layering); thermodynamic properties of the columnar air mass (temperature, pressure, concentrations of all three phases of water); the state and characteristics of the underlying surface (the lower boundary condition); processes within the column that create or modify all of these characteristics (including precipitation, evaporation, and the generation of condensation nuclei); and radiatively significant particulates, aerosols, and gases. Basic, continuous observations must be made as often as is feasible within budgetary constraints. For limited time periods, these observations will be supplemented by directed IOPs providing higher resolution or difficult-to-obtain in situ data.

Beyond simply providing the data streams, it is imperative to determine their character and quality as early as possible in the observational program. This evaluation will provide the basic operational understanding of the data necessary for an ongoing program of such scope. Although there will be both reason and ample opportunity to develop a further understanding of the ARM observations over the course of the program, it is important to investigate and ensure the data quality as soon as possible. In this regard, early and definitive quality measurement experiments (QMEs) will establish confidence in the measurements. 
The SGP CART site is the first of several global locations chosen and instrumented for data collection. As summarized in a draft report by Sisterson and Barr, the scientific issues to be addressed by using data from a midlatitude continental CART observatory include the following:

- Radiative transfer under conditions of clear sky and general cloudiness

- Scattering and absorption in cloudy atmospheres

- Cloud formation, maintenance, and dissipation

- Nonradiative flux parameterizations

- The role of surface physical and vegetative properties in the column energy balance

- Other complications in the radiative balance in the atmosphere, particularly those due to aerosols, cloud condensation nuclei (CCN), and cloud-aerosol radiative interactions

- Feedback processes between different phenomena and different domains

The variety, density, and atmospheric volumetric coverage of the SGP instrumentation will be more comprehensive than that at any other ARM site, and the SGP site will experience a wider variety of atmospheric conditions than any other ARM site. The resulting data will support a greater range and depth of scientific investigation than data from any other location, making it imperative for the ARM Program to develop and maintain a high-quality, continuous data stream from the SGP site.

In the process of distilling the measurements required by the Science Team proposals, the Experiment Support Team (EST) and the Science Director developed a set of general measurement strategies (GMS), which represent groups of experiments requiring measurements with similar characteristics. The initial GMS are designed to quantify the instantaneous radiative flux (IRF) and to support the requirements of the single-column model (SCM) data assimilation (DA) and hierarchical diagnosis (HD) research. The EST, Instrument Team (IT), and others have established a set of critical measurements that has driven much of the SGP site development to date. The EST documented these measurements in 1992 and continues to work with the IT to 
prioritize the scheduling of instrument deployment. Because the site implementation has been phased, IRF measurements began first. They have been followed by the initiation of episodic measurements designed to support the SCM, DA, and HD experiments. This six-month period will include activities that will support a major portion of each of the GMS.

Budget limitations and procurement delays have somewhat slowed the site development and completion of the site. The emphasis in this six-month period will be on consolidating the existing suite of instruments and supporting systems and on resolving associated data quality issues. A design review process has been underway for new systems scheduled for the site (including the calibration and aerosol facilities), which will address installation, operational, safety, and quality issuc.. Our ability to meet the long-term observational needs of the Science Team will depend on the continued development, acquisition, and deployment of instruments (especially at the boundary and extended facilities), as well as careful orchestration of IOPs and collaborative campaigns during the next few years. Instruments will be acquired and installed (especially at the extended facilities, and especially aerosol and calibration instrumentation).

The late summer, fall, and early winter at the SGP site typically include a wide range of conditions -- from high humidity, heat, and haze; through organized convective activity producing significant precipitation events with associated stratocumulus decks; to fair, cool weather with cirrus. In response to the sessions at the March 1994 Science Team meeting and subsequent surveys by the EST, site activities during July-December 1994 will expand to include a wider suite of continuous measurements, including an enhanced rawinsonde launch schedule. Special operations will include four IOPs, two to support the SCM group, one to support the unmanned aerospace vehicle (UAV), and one to support GEWEX (Global Energy and Water Cycle Experiment) Continental-Scale International Project (GCIP) activities.

We will continue the suite of basic IRF measurements, including digital sky imagery, cloud base observations, and hourly visual observations of sky conditions above the central facility during operator hours. Routine observations will include five daily balloon-borne sounding system (BBSS) launches on Monday-Friday (including holidays) at the central facility and four daily BBSS launches on Monday-Friday (including holidays) at the boundary facilities to support the atmospherically emitted radiation interferometer (AERI), the solar radiance transmission interferometer (SORTI), the Spinhirne micropulse lidar ceilometer, and vertical-profiling remote-sensing instrumentation. We expect the interim whole-sky imaging system to be replaced by a day-night system and the solar and infrared radiation observing 
system (SIROS) installation at the central facility to be completed with the installation of new shadow arms; both of these improvements are important elements in the IRF measurements.

During this six-month period, we will also address more of the SCM, DA, and HD measurement needs with eddy correlation measurements at the central facility and with radar and acoustic profiling at two frequencies; with surface data collection from nine more fully developed extended facilities; and with periods of continuous measurement of integrated liquid and cloud water plus frequent temperature, humidity, and wind profiles from the BBSSes at the three boundary facilities. A fourth boundary facility at Purcell, Oklahoma, will be established after October 1, 1994, specifically to improve measurements of divergence and advective tendency, in accordance with SCM requirements. Eddy correlation instrumentation is expected to arrive in July or August at the central facility and at several extended facilities in the fall. Seasonal IOPs to support the SCM research will occur again in July and October. Both of these IOPs will involve 21 days of synchronized rawinsonde launches from the central and boundary facilities every $3 \mathrm{hr}$. An IOP for in situ observation of cloud optical properties has been deferied until the spring of 1995 .

Site operations will continue to support activities necessary for the IDP, including field adaptation of the AERI and SORTI and field testing of the SORTI, the ultraviolet (UV) spectral radiometer, and the Spinhirne micropulse lidar ceilometer.

A campaign IOP scheduled for August in collaboration with the GEWEX/GCIP program will involve BBSS launches during weekends at the central facility and boundary racilities, as well as an extra daily launch at the central facility and three boundary facilities. The UAV is expected to return for further tests and radiometric observations during the October SCM IOP.

In summary, our goal for this six-month period is to provide the Science Team with a suite of measurements that will support a wide range of research, while establishing solid instrument calibration and maintenance procedures and continuing the series of QMEs. Data quality assurance efforts are central to the success of the entire program. 


\section{ESTABLISHMENT OF ROUTINE SITE OPERATIONS}

The ARM Program Plan states that the comparison of model results with observations will continue throughout the lifetime of the site. This approach is the primary rationale for the establishment of decade-long routine operations at the SGP CART site. This strategy is mirrored in the experimental designs of the individual Science Team members. The experiment operations plans (EOPs) are a joint effort between the EST and Science Team members to implement the experimental designs of individual Science Team members. This site mission report collectively captures Science Team members' data stream requirements. The EOPs are sorted into the four GMS categories. The locations and configurations of the various facilities within the SGP CART site, the instrumentation, the operation of the site, and budget considerations are optimized to meet the objectives of the GMS categories.

The overwhelming majority of the measurements with the highest priority, on which the existing experimental designs are based, are regular (i.e., routine) observations. Continuous observations are also specified in the ARM Program Plan because of their utility in offsetting the lack of complete geographic coverage of the CART site. Implicit in the philosophy of choosing just a few observational locations was the understanding that long time series of data could sample enough of the natural variability to constitute a useful surrogate for spatial statistics, both within and beyond the bounds of the CART site. The heart of any statistical study is an uninterrupted sequence of high-quality observations; hence, developing and maintaining a robust observational facility as soon as possible is crucial.

Scientifically and logistically, routine operations will serve as the basis and background for all nonroutine operations, including QMEs, instrument development activities, IOPs, and collaborative campaigns directed toward obtaining difficult-to-gather or expensive in situ data. Consequently, development and validation of the basic observations retain top priority. Site development has progressed sufficiently to support several IOPs during this six-month period, both to fill measurement needs unmet during routine operations, and to support collaborative campaigns.

The Site Scientist Team (SST) will play a role in the establishment of routine operations, providing guidance to the site operations manager and his staff on scientific matters related to the data stream, answering questions from operations personnel concerning potential instrument problems, reviewing instrument maintenance and calibration schedules and procedures, reviewing designs for infrastructure supporting new instruments, contributing to the design of the 
standard operating procedures, reviewing and developing plans for special operations, and helping to establish forecast support for routine and special operations. The SST, in cooperation with instrument mentors, will generally oversee the quality control effort at the CART site, a continuous activity that includes daily monitoring of the CART data streams in collaboration with the staff at the central facility and the development of a data quality assurance plan that will address the data originating at the SGP site.

During this six-month period, a high priority will again be comparison of similar data streams from different instrument packages, a natural and obvious complement to the efforts of the instrument mentors. A number of QMEs developed by instrument mentors, the SST, or the EST might be conducted by employing routine observations. Examples include (1) comparison of water vapor profiles retrieved from the microwave radiometer (MWR) integrated vapor with the BBSS moisture profile; (2) comparison of calculated brightness temperatures (using the line-by-line radiative transfer model [LBLRTM]) at the specific wave numbers at which the MWR operates to the brightness temperatures observed by the MWR; (3) comparison of the cloud base heights derived from the Belfort and Spinhirne ceilometers with the cloud base height derived from the whole-sky imager (WSI); (4) intercomparison of the observed and calculated broadband radiative surface fluxes; (5) virtual temperature and velocity profiles from the BBSS and the 915- and 50-MHz profilers; (6) temperature, humidity, and pressure measurements from the surface meteorological observation station (SMOS), the 60-m tower, and the energy balance Bowen ratio (EBBR) system; and (7) momentum, heat, and moisture fluxes derived from the EBBR and eddy correlation (EC) systems. These studies will evaluate the vendor-specified operating ranges, precision, and accuracy of the CART instruments. A more subtle task will be the comparison of observations of different parameters to determine if they make physical sense in the context of changing conditions.

\subsection{Routine Operations on May 31, 1994}

\subsubsection{Instruments and Observational Systems}

The accomplishments of the site development efforts are most evident at the central facility, with its functioning power and data infrastructure and an impressive array of instruments. Ten extended facilities (including the subset of instrumentation at the central facility) have at least a partial suite of instruments in place, and three temporary boundary facilities have been functioning since January 1994. Figure 1 is a map of the SGP site, highlighting the locations of the developed extended and boundary facilities. The systems and 


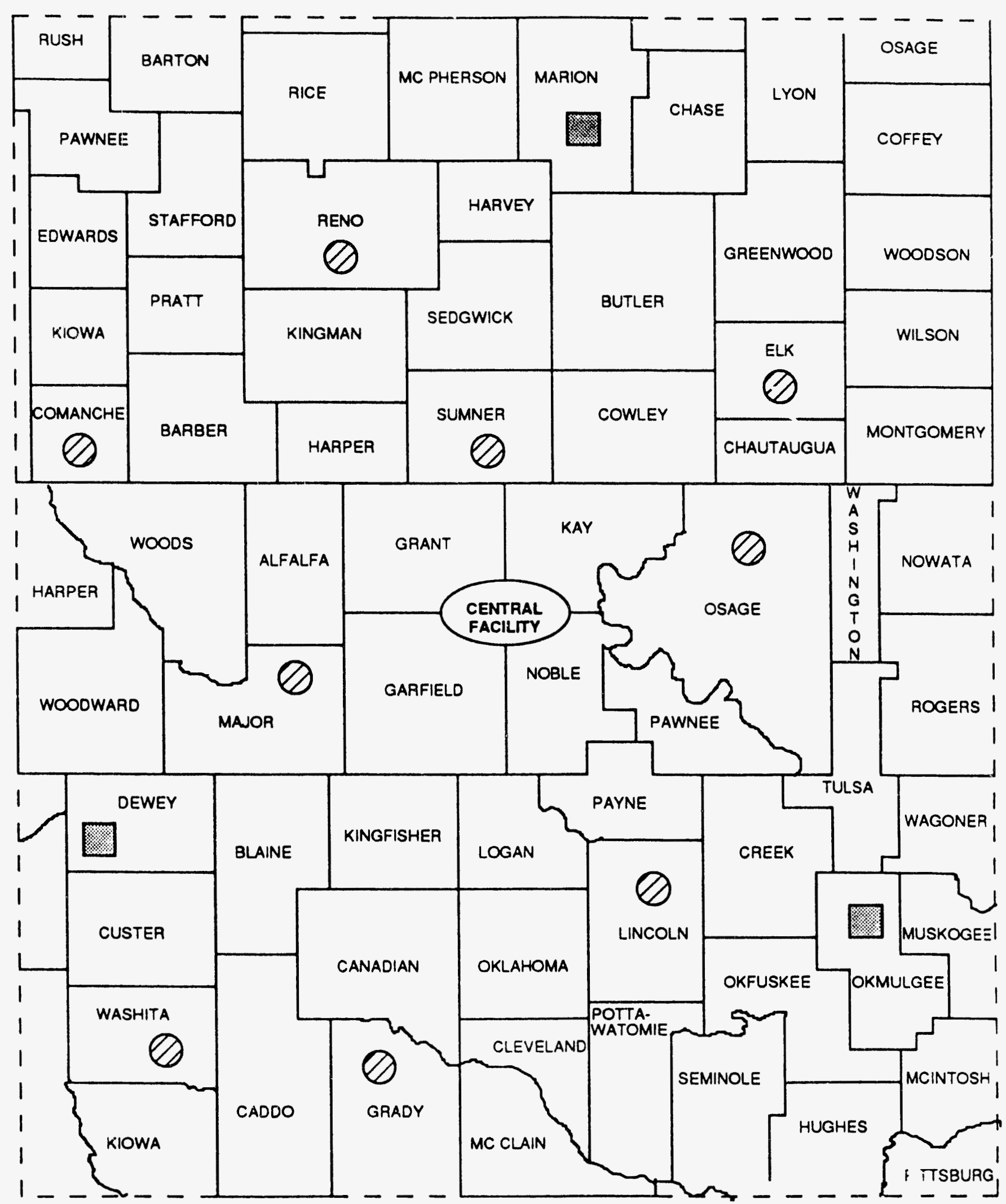

Developed Extended Facilities Boundary Facilities

FIGURE 1 Overall View of the SGP CART Site 
instruments in place are summarized in Tables 1 and 2 . The auxiliary facilities, which are intended to be the base for the three-dimensional observations of the cloud field over the central facility, will not be developed until plans for whole-sky imaging are more mature.

\subsubsection{Launch Schedule for BBSSes}

Until the full suite of remote-sensing systems is deployed to perform deep, detailed wind, temperature, and moisture soundings of the troposphere under a wide range of conditions, the BBSS will continue to be an expensive workhorse because of the cost of expendables and manpower associated with an ambitious rawinsonde launch schedule. The number of BBSS launches sitewide should eventually be reduced to a minimum needed to support routine cross checks on the remotely sensed measurements, but we are a number of years from that goal. In direct response to definitions of Science Team requirements (as summarized in Appendices A and B in the January-June 1994 Site Scientific Mission Plan and reiterated at the March 1994 Science Team meeting), the frequency of routine launches has been increased at the central facility and boundary facilities during this six-month period. Routine operations will include five daily launches at the central facility and four daily launches at the boundary facilities (see Section 4.2.6). The new launch times at the central facility were chosen to facilitate IRF and IDP research, and the launch times at the boundary facilities were chosen to facilitate SCM and DA/HD research and to complement and extend the wider network of National Weather Service (NWS) launches.

The two orbiting satellites (National Oceanic and Atmospheric Administration [NOAA] 11 and 12) both pass over the SGP CART site twice daily at times of low sun elevations, both in the morning (0630 and 0830, respectively) and evening (1830 and 2030, respectively, local time). Furthermore, only half of the overpasses of both satellites have the highest elevation angles (smallest zenith angles) above $45^{\circ}$. The IRF Science Team members have agreed that launching radiosondes with satellite overpasses is not beneficial because of the low sun angles and low satellite elevations at the SGP CART site.

All three boundary facilities will launch radiosondes every $6 \mathrm{hr}$, centered about the NWS launch schedule of 0000 and 1200 Greenwich Mean Time (GMT). Although the SCM Science Team members would like launches every $3 \mathrm{hr}$, the current budget can only support launches every $6 \mathrm{hr}$ during this six-month period. 
TABLE 1 Instruments and Observational Systems in Place at the Central, Boundary, and Auxiliary Facilities on May 31, 1994

\section{Central Facility}

Radiometric Observations

AERI

$\mathrm{Br}^{\mathrm{M}} \mathrm{db}$ dband Solar Radiation Network (BSRN)

Pyranometer (ventilated)

Pyranometer (ventilated, shaded)

Pyrgeometer (ventilated, shaded)

Normal-incidence pyrheliometer (NIP) on tracker

Multifilter rotating shadowband radiometer (MFRSR)

SORTI (limited operations in test mode)

Pyranometer (upwelling, above wheat at $25 \mathrm{~m}$ on $60-\mathrm{m}$ tower)

Pyrgeometer (upwelling, above wheat at $25 \mathrm{~m}$ on 60 -m tower)

Multifilter radiometer (upwelling, at $10 \mathrm{~m}$ )

Multifilter radiometer (upwelling, above wheat at $25 \mathrm{~m}$ on $60-\mathrm{m}$ tower)

Wind, Temperature, and Humidity Sounding Systems

\section{BBSS}

915-MHz profiler with RASS (radio acoustic sounding system)

$50-\mathrm{MHz}$ profiler with RASS

MWR

Heimann infrared thermometer

Cloud Observations

WSI

Belfort laser (interim) ceilometer

Micropulse lidar (IDP) ceilometer

Extended Facility Component

SIROS

Pyranometer (ventilated)

Pyrgeometer (ventilated)

NIP on tracker

MFRSR

Pyranometer (upwelling, at $10 \mathrm{~m}$ )

Pyrgeometer (upwelling, at $10 \mathrm{~m}$ )

EBBR

SMOS

Others

Temperature and humidity probes at $60 \mathrm{~m}$ on tower

\section{Boundary Facilities}

Limited implementation (fielding of BBSSes for IOPs and continuous operation of the MWR) near Hillsboro, Kansas; Vici, Oklahoma; and Morris, Oklahoma

\section{Auxiliary Facilities}

None in preparation 
TABLE 2 Instruments and Observational Systems in Place at the Extended Facilities on May 31, 1994

\begin{tabular}{|c|c|c|c|c|c|}
\hline Location & SMOS & SIROS & EBBR & $\mathrm{EC}$ & Data Intake \\
\hline \multicolumn{6}{|l|}{ Kansas } \\
\hline Hillsboro & - & $*$ & * & - & $*$ \\
\hline Ashton & $\mathbf{X}$ & $\mathbf{x}$ & $\mathrm{X}$ & - & $\begin{array}{l}\text { Coded switch } \\
\text { (extended facility } \\
\text { code operations } \\
\text { switch, EFCOS) }\end{array}$ \\
\hline Coldwater & $\mathbf{X}$ & $*$ & $\mathbf{X}$ & - & $\begin{array}{l}\text { EBBR by modem, } \\
\text { SMOS by diskette }\end{array}$ \\
\hline Plevna & $*$ & $*$ & $\mathbf{X}$ & - & Modem \\
\hline Elk Falls & * & * & $\mathbf{X}$ & - & Diskette \\
\hline Tyro & - & * & - & * & $*$ \\
\hline Towanda & * & * & - & * & * \\
\hline Larned & * & $*$ & - & * & * \\
\hline LeRoy & * & * & - & * & * \\
\hline Hesston & * & $*$ & - & * & $*$ \\
\hline \multicolumn{6}{|l|}{ Oklahoma } \\
\hline Central Facility & $\mathbf{x}$ & $\mathbf{X}$ & $\mathbf{X}$ & * & $\begin{array}{l}\text { Coded Switch } \\
\text { (EFCOS) }\end{array}$ \\
\hline Ringwood & $\mathbf{x}$ & $\mathbf{x}$ & $\mathbf{x}$ & - & $\begin{array}{l}\text { Coded switch } \\
\text { (EFCOS) }\end{array}$ \\
\hline Okmulgee & * & * & - & * & * \\
\hline Meeker & $\mathbf{x}$ & * & $\mathbf{x}$ & - & $\begin{array}{l}\text { EBBR by modem, } \\
\text { SMOS by diskette }\end{array}$ \\
\hline Cordell & - & * & $\mathbf{X}$ & - & Modem \\
\hline El Reno & - & * & * & - & * \\
\hline Pawhuska & - & * & $\mathrm{X}$ & - & Diskette \\
\hline Vici & - & $*$ & - & * & $*$ \\
\hline Morris & - & * & * & - & * \\
\hline Ft. Cobb & - & * & - & * & $*$ \\
\hline Cyril & $*$ & * & - & * & * \\
\hline Byron & * & $*$ & - & * & * \\
\hline Cement $^{b}$ & - & - & $\mathrm{X}$ & - & Modem \\
\hline
\end{tabular}

a The central facility includes the complement of instruments at an extended facility. These are listed in Table 1 and are not repeated here. $X$ means installed, * means planned for installation, - means no installation currently planned, "diskette" means data are retrieved manually on diskette, "modem" means data are retrieved remotely by telephone, "coded switch" means data are retrieved automatically by computer through coded switches. All sites will eventually transfer data by coded switches to the central facility. Ten of the sites are collocated with either an Oklahoma Mesonet or an NWS site, so that a SMOS would be redundant and is not planned. Each site will have either an EBBR (over pasture) or an EC (over cropland) system.

b Temporary facility to support the 1994 GEWEX study. 
The central and boundary facilities will be staffed from 0530 to 2100 and 2330 to 0330 local time, Monday through Friday, including holidays. During IOPs they will be staffed $24 \mathrm{hr}$ a day, seven days a week, including holidays.

A fourth boundary launch site is being planned, and an interim facility will be in place by October 1, possibly near the Purcell, Oklahoma, NOAA profiler. Possible fifth and sixth boundary facilities are currently under consideration.

The SCM IOPs scheduled for July and October require launches at the central and boundary facilities every $3 \mathrm{hr}$ for 21 days. Extra launches at the central facility and three boundary facilities are scheduled for most of August, to support the GCIP IOP (see Section 4.2.6).

\subsubsection{Observations, Measurements, and External Data}

The observations being delivered to the Experiment Center from the SGP CART site as of May 31, 1994, are summarized in Table 3. Platforms listed as "NOT available" are undergoing evaluation. The other instruments operating at the site (Table 1) that are not in Table 3 either are still under evaluation by the instrument mentors or are awaiting the creation of the data intake modules necessary to add their data to the SGP data stream.

The measurements being produced at the Experiment Center as of May 31, 1994, for distribution to the Science Team are listed in Table 4. This summary includes both the measurements derived from the SGP CART site data and the data streams from sources external to ARM (e.g., the gridded data from the NWS's Nested Grid Model [NGM]). Table 5 lists the external data that currently suppleinent the SGP site data.

Tables 3-5 reflect the data streams required for experimental designs and EOPs. Separate documentation of the experimental designs is given in the Reference Manual for CART Experiment Design: Documentation of Measurements According to General Measurement Strategies (January 31, 1992, Version 1.0) that is distributed by the Modeling Team leader at Lawrence Livermore National Laboratory, Livermore, California 94550. 
TABLE 3 CART Observation Status on May 31, 1994

\begin{tabular}{lll}
\hline Observation & Platform & Comments \\
\hline
\end{tabular}

From the BBSS

Sonde temperature profile

Sonde relative humidity profile

Sonde pressure profile

Sonde wind speed profile

Sonde wind direction profile

\section{From the MWR}

Column-integrated precipitable water vapor

Column-integrated liquid water path

23.8- $\mathrm{GHz}$ brightness temperature

31.4-GHz brightness temperature

Infrared $(9.5-11.5 \mu \mathrm{m})$ sky temperature

From the AERI

Wave number $\left(520-1800 \mathrm{~cm}^{-1}\right)$

Mean infrared radiance spectra ensemble

Standard deviation of spectra ensembie

Wave number $\left(1800-2725 \mathrm{~cm}^{-1}\right)$

Mean infrared radiance spectra ensemble

Standard deviation of spectra ensemble

Mean radiance at 675-680, 700-705, 985-990, $2295-2300,2282-2287,2510-2515 \mathrm{~cm}^{-1}$

Standard deviation of the radiance at 675-680, 700-705, 985-990, 2295-2300, 2282-2287, $2510-2515 \mathrm{~cm}^{-1}$

Brightness temperature at 675-680, 700-705, 985-990, 2295-2300, 2282-2287, $2510-2515 \mathrm{~cm}^{-1}$

From the EBBR (at 10 sites)

Sensible heat flux to surface

Latent heat flux to surface

Net radiation flux to surface

Soil heat flux to surface

Top and bottom temperatures

Top and bottom relative humidities

Top and bottom vapor pressures

Atmospheric pressure

Soil moistures at five points

Soil temperatures at five points

Scalar and resultant wind speeds

Mean and standard deviation of wind direction
sgpsondeC1.al

sgpsondeCl.al

sgpsondeCl.al

sgpsondeC1.al

sgpsondeCl.al

sgpmwrlosC1.al sgpmwrlosC1.al sgpmwrlosC1.al sgpmwrlosC1.al sgpmwriosC1.al

Available $^{\mathrm{a}}$

Available

Available

Available

Available

Available

Available

Available

Available

Available

sgpaerich1C1.al sgpaerich 1C1.al sgpaerich 1C1.al sgpaerich1C1.al sgpaerich 1C1.al sgpaerich1C1.al sgpaerisummaryC1.al

sgpaerisummaryC1.al

Available Available Available Available Available Available Available

Available

sgpaerisummary C1.al

Available
sgp30ebbrE4.al sgp30ebbrE4.al sgp30ebbrE4.al sgp30ebbrE4.al sgp30ebbrE4.al sgp30ebbrE4.al sgp30ebbrE4.al sgp30ebbrE4.al sgp30ebbrE4.al sgp30ebbrE4.al sgp30ebbrE4.al sgp30ebbrE4.al
Available Available Available Available Available Available Available Available Available Available Available Available 
TABLE 3 (Cont.)

\begin{tabular}{lll}
\hline Observation & Platform & Comments \\
\hline
\end{tabular}

From the SMOS (at 5 sites)

Mean and standard deviation of wind speed Mean and standard deviation of wind direction Vector-averaged wind speed

Mean and standard deviation of temperature Mean and standard deviation of relative humidity

Vapor pressure

Mean and standard deviation of barometric pressure

Snow depth

Precipitation total

\section{From the SIROS}

Direct beam-normal solar irradiance

Downwelling diffuse solar irradiance

Downwelling hemispherical solar irradiance

Upwelling hemispherical solar irradiance

Upwelling hemispherical infrared irradiance

Downwelling hemispherical infrared irradiance

Hemispheric downward solar irradiance (415, $500,610,665,862$, and $940 \mathrm{~nm}$ )

Hemispherical downward total solar irradiance

Diffuse hemispherical downward solar irradiance $(415,500,610,665,862$, and $940 \mathrm{~nm})$

Diffuse hemispherical downward total solar irradiance

Direct beam-normal solar irradiance $(415,500$, $610,665,862$, and $940 \mathrm{~nm}$ )

Direct beam-normal total solar irradiance

From the Belfort Ceilometer

Cloud base height

From the Profiling Radars

915-MHz wind speed profile

915-MHz wind direction profile

915-MHz virtual temperature profile

$50-\mathrm{MHz}$ wind speed profile

$50-\mathrm{MHz}$ wind direction profile

$50-\mathrm{MHz}$ virtual temperature profile
sgp30smosE4.al

sgp30smosE4.al

sgp30smosE4.al

sgp30smosE4.al

sgp30smosE4.al

sgp30smosE4.al

sgp30smosE4.al

sgp30smosE4.al

sgp30smosE4.al

sgpsirosC1.al

sgpsirosC1.al

sgpsirosC1.al

sgpsirosCl.al

sgpsirosC1.al

sgpsiros $\mathrm{Cl}$.al

sgpsirosCl.al

sgpsirosCl.al

sgpsirosC1.al

sgpsirosC1.al

sgpsirosC1.al

sgpsirosC1.al

Available

Available

Available

Available

Available

Available

Available

Available

Available

Available $^{b}$

Available $^{b}$

Available $^{b}$

Available $^{b}$

Available $^{b}$

Available $^{b}$

Available $^{b}$

Available ${ }^{b}$

Available $^{b}$

Available ${ }^{b}$

Available $^{\mathrm{b}}$

Available $^{\mathrm{b}}$

Available

sgp915rwpwindC1.a2

sgp915rwpwindC1.a2

sgp915rwptempC1.a2

sgp50rwpwind $\mathrm{Cl}$.a2

sgp50rwpwind 1.22

sgp50rwptempC1.a2
Available $^{\mathrm{b}}$

Available $^{b}$

Available $^{b}$

Available $^{b}$

Available $^{\mathbf{b}}$

Available $^{b}$ 
TABLE 3 (Cont.)

Observation

Platform

Comments

From Future Instruments

Cloud base height (Spinhime micropulse lidar)

UV spectral radiometer

Interim whole-sky imager

- IDP iesting in $1994^{c}$

IDP testing in $1994^{c}$

Available

a Available means that an instrument is in the field producing some level of data. However, the data may not have been released by the Instrument Mentor or the Experiment Center and thus may not be available to the Science Team members.

b Available to beta users.

c May be available in the fall of 1994. 
TABLE 4 CART Measurement Status on May 31, 1994

$\begin{array}{lll}\text { Measurement } \quad \text { Platform } & \text { Comments }\end{array}$

From the SIROS

Direct beam-normal solar irradiance

Calculated downward hemispherical diffuse solar irradiance

Downwelling hemispherical solar irradiance

Solar zenith angle used in calculation

,

Comments

\section{From the $M W R$}

Average (5-min) column-integrated water vapor Average (5-min) column-integrated liquid water Average (5-min) blackbody equivalent brightness temperature

Water vapor density profile

sgpbsrncalcC1.c1

sgpbsrncalcC1.c1

sgpbsrncalcC1.c1

sgpbsrncalcC1.c1

sgp5mwravgCl.c1

sgp5mwravgC1.c1

sgp5mwravgC1.c1

sgpmwrprofCl.cl

sgpsirosopdepthCl.cl

sgpsirosopdepthC1.c1

sgpsirosopdepthC1.c1

Available

Available

Available

Available for

central facility

Available

Available

Available

Optical depth calculation standard error

$(415,500,610,665,862,940 \mathrm{~nm})$

From Science Team Algorithms

Reflected solar flux at top of atmosphere (TOA) (Cess algorithm)

Input for LBLRTM

Output from LBLRTM (infrared spectral irradiance at $520-3020 \mathrm{~cm}^{-1}$ )

Difference of observations and calculations of infrared irradiances

Map of wave number to physical process

Statistical summary of radiance residuals

Statistical summary of hourly AERI radiance

Available

Available

Available

Available

Available

Available

Available

a Available means that an instrument is in the field producing some level of data. However, the data may not have been released by the Instrument Mentor or the Experiment Center and thus may not be available to the Science Team members. 


\section{TABLE 5 CART External Data Status on May 31, 1994}

$\begin{array}{lll}\text { Measurement } & \text { Platform }\end{array}$

From Satellites

GOES (geostationary orbiting Earth satellite) visible brightness

GOES IR (infrared) radiance $(11.2 \mu \mathrm{m})$,

IR temperature $(12.7,11.2,6.7 \mu \mathrm{m})$

AVHRR visible albedo (two channels),

IR radiance (three channels), and

IR temperature

\section{From GOES Data as Derived by Minnis}

Cloud fraction, cloud visible optical depth, cloud infrared optical depth, cloud normal

sgpgoesvisX1.b1

sgpgoesirX1.bl

sgpavhrrX1.b1

NOT available emittance, cloud radiating center altitude (near top for thick clouds), cloud top altitude, cloud radiating center temperature, cloud top temperature, cloud thickness (very crude estimate), cloud narrowband reflectance (mean of raw observations), cloud narrowband albedo (atmosphere and surface removed), cloud equivalent blackbody temperature (radiance-averaged raw observations), clear-sky reflectance, clear-sky-equivalent blackbody temperature

From the Smoothed Nested-Grid Model Data Products

Temperature (3-D [three dimensional]), ngm250 NOT available ${ }^{b}$ relative humidity (3-D), horizontal wind components (3-D), vertical (omega) wind component (3-D), geopotential heights (3-D), Surface and tropopause pressure (2-D), 12-hr precipitation (2-D)

Surface pressure (reduced to sea level), ngm250derived NOT availableb tropopause pressure, tropopause temperature, temperature $(T),-\left(u^{*} d T / d x+v^{*} d T / d y\right)$, water vapor mixing ratio, $-\left(u^{*} d q / d x+\right.$ $\left.v^{*} d q / d y\right)$, horizontal wind components $(u, v)$, $(d u / d x+d v / d y),-\left(u^{*} d u / d x+v^{*} d v / d y\right)$ and - $\left(u^{*} d v / d x+v^{*} d v / d y\right)$, geopotential height (Z), $d z / d x$ and $d z / d y, d 2 T / d x 2, d 2 T / d y 2, d 2 q / d x 2$, $\mathrm{d} 2 \mathrm{q} / \mathrm{dy} 2, \mathrm{~d} 2 \mathrm{w} / \mathrm{d} \times 2, \mathrm{~d} 2 \mathrm{u} / \mathrm{dy} 2, \mathrm{~d} 2 \mathrm{v} / \mathrm{d} \times 2, \mathrm{~d} 2 \mathrm{v} / \mathrm{dy} 2$

From the Forecast Systems Laboratory Maps Model

Gridded meteorological fields (eight daily) of height, temperature, relative humidity, and Dsgpallmaps60X1.cl Available horizontal wind components, every $25 \mathrm{kPa}$ from the surface to $100 \mathrm{kPa}$, covering most of North America (subsets also available) 
TABLE 5 (Cont.)

Measurement

Platform

Comments

From the Forecast Systems Laboratory Maps Model (Cont.)

Gridded meteorological fields (cight daily) of

Dsgpmaps60X1.cl

Available

height, temperature, relative humidity, and horizontal wind components, every $25 \mathrm{kPa}$

from the surface to $100 \mathrm{kPa}$, covering most of the SGP CART site

Derived variables from Mesoscale Analysis and Prediction System data similar to those in

Dsgpmaps60derivX1.c1 Available ngm250derived

From the National Meteorological Center ETA Model

Gridded meteorological fields (four daily) of

Dsgpalleta90X1.c1

Available ${ }^{c}$

height, temperature, relative humidity, and

horizontal wind components, every $50 \mathrm{kPa}$

from the surface to $100 \mathrm{kPa}$, covering most of North America (subsets also available)

Gridded meteorological fields (four daily) of height, temperature, relative humidity, and horizontal wind components, every $50 \mathrm{kPa}$ from the surface to $100 \mathrm{kPa}$, covering most of the SGP CART site

Dsgpeta90X1.c1

Available $^{c}$

From the NOAA Wind Profiler Demonstration Network

Profile of wind components

Derived variables from NOAA profilers, especially divergence

From the National Weather Service

Surface hourly observations

Upper air observations

nws-sfc

nws-upair

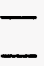

-

Available

Available

From the Kansas Surface Mesonetwork

Hourly observations of air temperature, relative

ka-mesonet

Available humidity, wind direction, wind speed, total solar radiance, total rainfall, and $10-\mathrm{cm}$ soil temperature 


\section{TABLE 5 (Cont.)}

\section{From the Oklahoma Mesonetwork \\ Hourly observations of air temperature, relative humidity, wind direction, wind speed, total \\ ok-mesonet Available solar radiance, total rainfall, and 5- and $10-\mathrm{cm}$ soil temperature}

a Available means that an instrument is in the field producing some level of data. However, the data may have not been released by the Instrument Mentor or the Experiment Center and thus may not be available to the Science Team members.

b Data are discontinued after June 2, 1994, and is being replaced by ETA model.

c Data are available after June 30, 1994.

\subsection{Site Development Activities}

\subsubsection{Facilities}

Much of the infrastructure at the central facility is complete, including the power, telephones, and fiber optic data network. The three IDP pads were successfully completed in time to host the Remote Cloud Sensing IOP in April 1994.

The AERI is installed in the optical trailer, but problems relative to an automatic liquid nitrogen supply await resolution during this six-month period. The resulting impact to site operations has limited operation of the AERI until a satisfactory sciution is found. Currently, site operations personnel are hand-filling the AERI during normal operation hours (once each morning and evening). They will continue to do so until the technical problems are resolved. During the SCM IOPs, site operators hand-fill the AERI with liquid nitrogen at the beginning of each of three shifts.

The SORTI was installed in the optical trailer in December 1993 and is still undergoing testing. The Spinhirne micropulse lidar has been operating intermittently in the optical trailer and is also being adapted. The Belfort ceilometer, which is operating about $3 \mathrm{~m}$ east of the optical trailer, has proven to be relatively robust. The WSI is located about $15 \mathrm{~m}$ south of the optical trailer, at a location high enough so that the optical trailer does not interfere with the field of view. 
Initial design requirements were reviewed (October 1993) for the calibration platform deck and wiring of the calibration trailer, and final design requirements are currently under review. Procedures are being developed to identify the number of sensors required, the required frequency of calibration for all radiometers at the SGP site, the frequency of sensor changeouts, and a methodology for tracking all sensors. The calibration trailer is tentatively scheduled for implementation in the fall of 1994.

Plans for the aerosol intake stack and other structures in the aerosol trailer were reviewed in December 1993. Final plans were developed in April 1994, and final drawings were received in May 1994. A statement of work is being generated for procurement, and the implementation of the facility is expected in mid to late summer of 1994. Instrumentation in the aerosol trailer will include an optical absorption system, an integrating nephelometer, an optical particle counter, a condensation particle counter, and an ozone monitor. (See Table 6.)

The site data system (SDS) will continue to evolve during this six-month period. The initial plan for automated electronic data transfers (via telephone) from all boundary facility instruments was implemented during the January SCM IOP. Experience has shown that this configuration is insufficient to support the data transfer from the boundary facilities, so a different configuration is being planned and will need to be implemented and tested. Each of the boundary facilities will have T-1 lines installed. All instruments at boundary facilities will be ingested locally (essentially via an Internet connection to the central facility). We expect the SDS to require one or more upgrades to support this critical expansion in capabilities. Further work is also needed to facilitate routine operations, particularly for assessment of instrument performance and data transfer, including a broader suite of data display capabilities. Once the SDS is near completion, procedures for system management and maintenance need to be written and transferred to site operations. Currently, data from the three boundary facilities are being sent weekly to the central facility by an overnight transport service.

The ten current extended facilities (including one temporary non-ARM site in support of GCIP and GCSS [GEWEX Cloud Study System] in the Little Washita watershed) will receive more complete instrumentation, and (operations budget permitting) six additional extended facilities may be established, as indicated in Table 7. The temporary EBBR near Cement in Grady County, Oklahoma, will not be moved to the El Reno, Oklahoma, site until late summer, as requested, in support of the 1994 field activities of the GEWEX. Ringwood and Ashton have a complete set of instrumentation. Only four SIROSes are available for installation in the 
TABLE 6 Observational Instruments and Systems Expected to be in Place at Central and Boundary Facilities by December 31, 1994

\section{Central Facility}

Radiometric Observations

AERI

Pyranometer (upwelling, above wheat at $25 \mathrm{~m}$ on 60 -m tower)

Pyrgeometer (upwelling, above wheat at $25 \mathrm{~m}$ on $60-\mathrm{m}$ tower)

Multifilter radiometer (upwelling, at $10 \mathrm{~m}$ )

Multifilter radiometer (upwelling, above wheat at $25 \mathrm{~m}$ on $60-\mathrm{m}$ tower)

All-weather cavity pyrheliometer ${ }^{a}$

UV spectral radiometer ${ }^{\mathrm{a}}$

Wind, Temperature, and Humidity Sounding Systems

BBSS

915-MHz profiler with RASS

$50-\mathrm{MHz}$ profiler with RASS

MWR

Heimann infrared thermometer

Cloud Observations

Interim WSI

Belfort laser (interim) ceilometer

Micropulse lidar (IDP) ceilometer

Instruments and Systems in the Aerosol Trailer

Optical absorption system ${ }^{2}$

Integrating nephelometer (1 lambda) ${ }^{\mathrm{a}}$

Optical particle counter ${ }^{2}$

Condensation particle counter ${ }^{a}$

Ozone monitor ${ }^{\mathrm{a}}$

Manifold sample system ${ }^{a}$

Instruments and Systems in the Calibration Trailer

Solar spectroradiometer ${ }^{b}$

Site reference cavity radiometer ${ }^{b}$

NIST (National Institute of Standards and Technology) standard lamps with controlled current source ${ }^{b}$

Reference blackbodyb

Optical breadboard system ${ }^{b}$

Extended Facility Components

SIROS

Pyranometer (ventilated)

Pyranometer (shaded, ventilated)

Pyrgeometer (shaded, ventilated)

Normal-incidence pyrheliometer (NIP) on tracker

MFRSR

Pyranometer (upwelling, at $10 \mathrm{~m}$ )

Pyrgeometer (upwelling, at $10 \mathrm{~m}$ )

SMOS

EBBR 
TABLE 6 (Cont.)

Others

Temperature and humidity probes at $60 \mathrm{~m}$ on tower

Eddy correlation systems near surface ${ }^{\mathrm{a}}$

Eddy correlation systems on $60-\mathrm{m}$ tower $^{\mathrm{a}}$

Boundary Facilities

Permanent installations ${ }^{a}$ are in place at Hillsboro, Kansas; Vici, Oklahoma; and Morris, Oklahoma. Each includes a BBSS and an MWR. A fourth BBSS site (possibly temporary) will be added by October 1, 1994, at a location to be determined.

Auxiliary Facilities

None in preparation

a Added after August 1994.

b Added after October 1994.

summer of 1994, and they have been prioritized for installation at Plevna, Cordell, Meeker, and Elk Falls. These and the remaining three extended facilities will require some or all of the following: installation of power and communications, construction of power and signal infrastructures, installation of automatic switches so that the SDS can interrogate extended facilities for data, and acquisition of suitably sized uninterruptable power supply (UPS).

The first three boundary facilities, temporarily installed in January 1994, initially support a BBSS and an MWR in close proximity to the NOAA 404-MHz profilers. The NOAA sites include a set of surface instrumentation comparable to the SMOS suite, and these data accompany the profiler data, as external data. Th $;$ schedule for installation of RASSes (radio acoustic sounding systems) on the NOAA profilers remains uncertain. These initial boundary facilities are a minimal, temporary arrangement sufficient to support the SCM IOPs.

Experience during the January SCM IOP and subsequent directed tests indicated that the current boundary facility locations are too close to the NOAA profilers, resulting in varying amounts of interference that produces data gaps in the high-altitude BBSS data. This problem led to specific questions about the Vaisala processing that sometimes excluded "good" data during specific conditions (i.e., nocturnal, low-level wind speed and direction profile data). Because the Vaisala system affords only a choice of unprocessed or processed data (not both), ARM had originally decided to take processed data. However, unanticipated problems make unprocessed data from the BBSS a requirement for at least some Science Team members. 
TABLE 7 Observational Instruments and Systems Expected to be in Place at Extended Facilities, Apart from the Central Facility, by December 31, 1994a

\begin{tabular}{|c|c|c|c|c|c|}
\hline Location & SMOS & SIROS & EBBR & $\mathrm{EC}$ & Data Intake \\
\hline \multicolumn{6}{|l|}{ Kansas } \\
\hline $\begin{array}{l}\text { Hillsboro } \\
\text { Ashton } \\
\text { Coldwater } \\
\text { Plevna } \\
\text { Elk Falls } \\
\text { Tyro } \\
\text { Towanda } \\
\text { Lamed } \\
\text { LeRoy } \\
\text { Hesston }\end{array}$ & $\begin{array}{l}- \\
\mathbf{X} \\
\mathbf{X} \\
\mathbf{X} \\
\mathbf{X} \\
\vdots \\
* \\
* \\
* \\
*\end{array}$ & $\begin{array}{l}* \\
\mathbf{X} \\
* \\
\mathbf{X} \\
\mathbf{X} \\
* \\
* \\
* \\
* \\
*\end{array}$ & $\begin{array}{l}* \\
\mathbf{X} \\
\mathbf{X} \\
\mathbf{X} \\
\mathbf{X} \\
- \\
- \\
- \\
- \\
-\end{array}$ & $\begin{array}{l}. \\
. \\
- \\
- \\
. \\
* \\
* \\
* \\
*\end{array}$ & $\begin{array}{c}* \\
\text { Coded switch } \\
\text { Coded switch } \\
\text { Coded switch } \\
\text { Coded switch } \\
* \\
* \\
* \\
* \\
*\end{array}$ \\
\hline \multicolumn{6}{|l|}{ Oklahoma } \\
\hline $\begin{array}{l}\text { Central Facility } \\
\text { Ringwood } \\
\text { Okmulgee } \\
\text { Meeker } \\
\text { Cordell } \\
\text { El Reno } \\
\text { Pawhuska } \\
\text { Morris } \\
\text { Vici } \\
\text { Ft. Cobb } \\
\text { Cyril } \\
\text { Byron } \\
\text { Cementb }\end{array}$ & $\begin{array}{l}\mathbf{X} \\
\mathbf{X} \\
\mathbf{X} \\
\mathbf{X} \\
- \\
- \\
- \\
- \\
- \\
- \\
\mathbf{X} \\
\mathbf{X}\end{array}$ & $\begin{array}{l}\mathbf{X} \\
\mathbf{X} \\
* \\
\mathbf{X} \\
\mathbf{X} \\
* \\
* \\
* \\
* \\
* \\
* \\
\mathbf{X} \\
-\end{array}$ & $\begin{array}{l}\mathbf{X} \\
\mathbf{X} \\
- \\
\mathbf{X} \\
\mathbf{X} \\
* \\
\mathbf{X} \\
* \\
- \\
- \\
- \\
\\
\mathbf{X}\end{array}$ & $\begin{array}{l}\mathbf{X} \\
- \\
* \\
- \\
- \\
- \\
- \\
- \\
\mathbf{X} \\
* \\
\mathbf{X} \\
\mathbf{X} \\
-\end{array}$ & $\begin{array}{c}\text { Coded switch } \\
\text { Coded switch } \\
* \\
\text { Coded switch } \\
\text { Coded switch } \\
{ }^{*} \\
\text { Coded switch } \\
* \\
* \\
* \\
* \\
* \\
-\end{array}$ \\
\hline
\end{tabular}

a $\mathrm{X}$ means installed, * means planned for installation, - means no installation currently planned, "diskette" means data are retrieved manually on diskette, "modem" means data are retrieved remotely by telephone, "coded switch" maans data are retrieved automatically by computer through coded switches. All sites will eventually transfer data by coded switches to the central facility. Eight of the sites are collocated with either an Oklahoma Mesonet or an NWS site, so that a SMOS would be redundant and is not planned. Each site will have either an EBBR (over pasture) or an EC (over cropland) system.

b Temporary facility to support the 1994 GEWEX study will be supported through August 1995. 
Hence, software was purchased in time for the spring IOP to allow unprocessed data to be collected from the BBSS at the three boundary facilities and also the central facility. However, on the basis of discussions at the Science Team meeting in early March 1994, processed temperature and humidity data but unprocessed wind data will be captured routinely after May 21,1994 . In short, this change will allow both processed and unprocessed data to be collected. In the meantime, unprocessed versus Vaisala-processed data are being compared in various ways, including model results from the LBLRTM.

Although all new shipments of radiosondes since April 1994 have been factory tuned to $401 \mathrm{MHz}$, potential interference by the NOAA profilers has been sufficient to cause the collocation requirement of boundary facility instrumentation and the profiler to be reexamined. On the basis of a detailed examination of the profiler interference problem (Report on the Balloon-Borne Sounding System [BBSS] Interference Testing by Jeanne Schneider, Les Showell, and John Carter) and on a detailed analysis of the collocation requirement for all instruments by the SST, all three boundary facilities will be moved at least $0.6 \mathrm{mi}$, but no more that $5 \mathrm{mi}$ from their current locations during this six-month period. All infrastructure support for the new boundary facilities (trailers, utilities, walkways, parking lots, lighting, fences, etc.) will be implemented before instrumentation is moved. Hence, boundary facilities will remain operational in their current locations until the new boundary locations are prepared. The goal is to move into the new locations before the October SCM IOP.

Recent discussions with some SCM Science Team members about potentially large uncertainties associated with divergence calculations derived from radiosonde data for the SGP CART site indicate that uncertainty might be reduced significantly with four boundary facility locations rather that the current three. Additional locations might further decrease uncertainty in divergence calculations, but the costs would be prohibitive. Decisions will be made after the October SCM IOP about whether more than four boundary facility locations are required.

Figure 2 summarizes site development activities. Milestones and complex tasks are distinguished from simple tasks or activities.

\subsubsection{Instruments}

The current status of and plans for instrument acquisition and deployment are summarized in Tables 8-10. During this six-month period, the central facility should gain the all-weather cavity pyrheliometer, the EC sensors (both on the tower and near the surface), and 


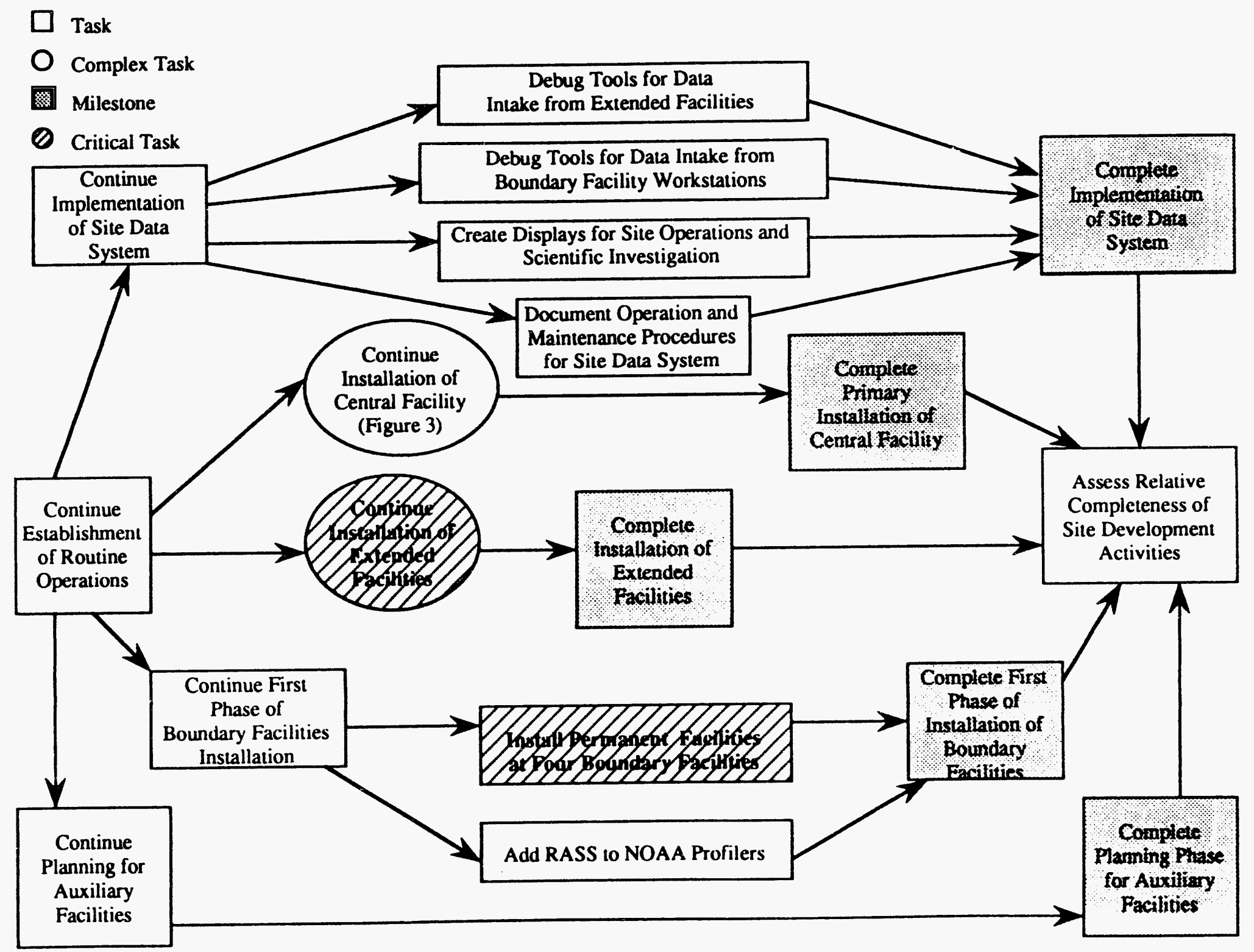

FIGURE 2 Site Development Activities to Establish Routine Operations 
TABLE 8 Status of Instrument Acquisition and Deployment on May 31, 1994

\begin{tabular}{|c|c|c|c|c|c|c|c|}
\hline Instrument & Mentor & Ordered & Delivered & $\begin{array}{c}\text { Central } \\
\text { Facility } \\
\text { Installation/ } \\
\text { Acceptance }\end{array}$ & $\begin{array}{l}\text { Extended } \\
\text { Facility } \\
\text { Installation/ } \\
\text { Acceptance }\end{array}$ & $\begin{array}{l}\text { Boundary } \\
\text { Facility } \\
\text { Installation/ } \\
\text { Acceptance }\end{array}$ & Comment \\
\hline WSI & Thorne & $5 / 93$ & $6 / 94$ & $\begin{array}{l}\text { Loaner in } \\
10 / 20 / 93\end{array}$ & - & - & $\begin{array}{l}\text { Loaner data analysis to } \\
\text { be done off site }\end{array}$ \\
\hline MWR & Liljegren & Done & $5 / 93$ & Done & - & Done & $\begin{array}{l}\text { Replace central facility } \\
\text { unit with new unit in } \\
11 / 93\end{array}$ \\
\hline IR thermometer & Liljegren & Done & Done & $11 / 93$ & - & Done & For use with the MWR \\
\hline BBSS & Lesht & Done & Done $(5 / 93)$ & Done & - & Done & $\begin{array}{l}\text { Interference by } \\
404-\mathrm{MHz} \text { profiler being } \\
\text { investigated }\end{array}$ \\
\hline EBBR & Cook & Done & $\begin{array}{l}\text { Ten units; two } \\
\text { more winter } \\
1994\end{array}$ & Done & $\begin{array}{l}\text { Ten units } \\
\text { installed }\end{array}$ & - & - \\
\hline 915-MHz RASS & Coulter & Done & Done & Done & - & - & $\begin{array}{l}\text { Transfer site data intake } \\
\text { to production system in } \\
11 / 93\end{array}$ \\
\hline 50-MHz RASS & Coulter & Done & Done & Done & - & - & - \\
\hline SMOS & Han & Done & Done & Done & $\begin{array}{l}\text { Five in } 4 / 93, \text { five } \\
\text { in winter } 1993\end{array}$ & - & $\begin{array}{l}\text { Five units stored at } \\
\text { central facility; five } \\
\text { more to be ordered } 1 / 93\end{array}$ \\
\hline $\begin{array}{l}\text { Belfor laser } \\
\text { ceilometer }\end{array}$ & Griffin & Done & $3 / 93$ & $11 / 93$ & - & - & Visual checks are OK \\
\hline Calibration facility & Wells & In process & Fall 1994 & $\begin{array}{l}\text { Second design } \\
\text { review } 5 / 94\end{array}$ & - & - & - \\
\hline
\end{tabular}


TABLE 8 (Cont.)

\begin{tabular}{|c|c|c|c|c|c|c|c|}
\hline Instrument & Mentor & Ordered & Delivered & $\begin{array}{c}\text { Central } \\
\text { Facility } \\
\text { Installation/ } \\
\text { Acceptance }\end{array}$ & $\begin{array}{c}\text { Extended } \\
\text { Facility } \\
\text { Installation/ } \\
\text { Acceptance }\end{array}$ & $\begin{array}{l}\text { Boundary } \\
\text { Facility } \\
\text { Installation/ } \\
\text { Acceptance }\end{array}$ & Comment \\
\hline 60-m tower & Cook & Done & Done & Done & - & - & $\begin{array}{l}\text { Relative humidity } \\
\text { sensor problems } \\
\text { resolved } 11 / 93\end{array}$ \\
\hline Eddy correlation & Hart, Cook & Done & $7 / 94$ & 7,94 & $7 / 94$ & - & $\begin{array}{l}\text { Testing at Argonne in } \\
\text { winter } 1993\end{array}$ \\
\hline \multicolumn{8}{|l|}{ Aerosols } \\
\hline $\mathrm{CCN}$ counter & Leifer & Cancelled & - & - & - & - & - \\
\hline $\begin{array}{l}\text { Manifold sample } \\
\text { system }\end{array}$ & Leifer & Done & - & $\begin{array}{l}\text { Final design } \\
\text { approval } 5 / 94\end{array}$ & - & - & - \\
\hline Ozone monitor & Leifer & Done & At EML ${ }^{a}$ & Done & - & - & - \\
\hline Collection system & Leifer & Cancelled & - & - & - & - & - \\
\hline $\begin{array}{l}\text { Optical absorption } \\
\text { system }\end{array}$ & Leifer & Done & Fall 1993 & - & - & - & - \\
\hline $\begin{array}{l}3-\lambda \text { integrating } \\
\text { nephelometer }\end{array}$ & Leifer & $\begin{array}{l}\text { Specifications } \\
\text { being written }\end{array}$ & $? ?$ & $? ?$ & - & - & - \\
\hline $\begin{array}{l}1-\lambda \text { integrating } \\
\text { nephelometer }\end{array}$ & Leifer & Done & At EML & $? ?$ & - & - & - \\
\hline $\begin{array}{l}\text { Optical particle } \\
\text { counter }\end{array}$ & Leifer & Done & At EML & $? ?$ & - & - & - \\
\hline
\end{tabular}


TABLE 8 (Cont.)

\begin{tabular}{|c|c|c|c|c|c|c|c|}
\hline Instrument & Mentor & Ordered & Delivered & $\begin{array}{c}\text { Central } \\
\text { Facility } \\
\text { Installation/ } \\
\text { Acceptance }\end{array}$ & $\begin{array}{l}\text { Extended } \\
\text { Facility } \\
\text { Installation/ } \\
\text { Acceptance }\end{array}$ & $\begin{array}{l}\text { Boundary } \\
\text { Facility } \\
\text { Installation/ } \\
\text { Acceptance }\end{array}$ & Comment \\
\hline $\begin{array}{l}\text { Condensation particle } \\
\text { counter }\end{array}$ & Leifer & Done & At EML & $? ?$ & - & - & - \\
\hline \multicolumn{8}{|c|}{ Broadband Radiometers - SIROS } \\
\hline MFRSR & Schmelzer & Done & Partial & $\begin{array}{l}\text { Revision } 7 \\
11 / 93\end{array}$ & $\begin{array}{l}\text { Two units in } \\
10 / 93\end{array}$ & - & \\
\hline $\begin{array}{l}\text { Broadband radiometer } \\
\text { loaners }\end{array}$ & DeLuisi & Done & Done & Done & - & - & $\begin{array}{l}\text { QME to be done to } \\
\text { compare Broadband } \\
\text { Solar Radiation } \\
\text { Network with SIROS }\end{array}$ \\
\hline $\begin{array}{l}\text { Pyranometer } \\
\text { (ventilated) }\end{array}$ & Deluisi & Partial & Partial & SIROS, $10 / 93$ & $\begin{array}{l}\text { Two SIROSes, } \\
12 / 93\end{array}$ & - & $\begin{array}{l}\text { Installations partial in } \\
10 / 93\end{array}$ \\
\hline $\begin{array}{l}\text { Pyranometer } \\
\text { (upwelling } 10 \mathrm{~m} \text { ) }\end{array}$ & DeLuisi & Done & Fall 1993 & SIROS, $12 / 93$ & $\begin{array}{l}\text { Two SIROSes, } \\
12 / 93\end{array}$ & - & - \\
\hline $\begin{array}{l}\text { Shaded pyranometer } \\
\text { (ventilated) }\end{array}$ & DeLuisi & $? ?$ & $? ?$ & $\begin{array}{l}\text { Needs new } \\
\text { shading disk } \\
\text { assembly }\end{array}$ & $\begin{array}{l}\text { Needs new } \\
\text { shading disk } \\
\text { assembly }\end{array}$ & - & - \\
\hline $\begin{array}{l}\text { Pyrgeometer (shaded } \\
\text { and ventilated) }\end{array}$ & DeLuisi & $? ?$ & $? ?$ & $\begin{array}{l}\text { Needs new } \\
\text { shading disk } \\
\text { assembly }\end{array}$ & $\begin{array}{l}\text { Needs new } \\
\text { shading disk } \\
\text { assembly }\end{array}$ & - & - \\
\hline $\begin{array}{l}\text { Pyrgeometer } \\
\text { (upwelling } 10 \mathrm{~m} \text { ) }\end{array}$ & DeLuisi & Done & Fall 1993 & SIROS, $12 / 93$ & $\begin{array}{l}\text { Two SIROSes, } \\
12 / 93\end{array}$ & - & - \\
\hline
\end{tabular}


TABLE 8 (Cont.)

\begin{tabular}{|c|c|c|c|c|c|c|c|}
\hline Instrument & Mentor & Ordered & Delivered & $\begin{array}{c}\text { Central } \\
\text { Facility } \\
\text { Installation/ } \\
\text { Acceptanice }\end{array}$ & $\begin{array}{l}\text { Extended } \\
\text { Facility } \\
\text { Installation/ } \\
\text { Acceptance }\end{array}$ & $\begin{array}{l}\text { Boundary } \\
\text { Facility } \\
\text { Installation/ } \\
\text { Acceptance }\end{array}$ & Comment \\
\hline Pyrheliometers (NIP) & Deluisi & Partial & Partial & SIROS, $10 / 93$ & $\begin{array}{l}\text { Two SIROSes, } \\
10993\end{array}$ & - & - \\
\hline Trackers for NIP & Deluisi & Partial & Partial & $\begin{array}{l}\text { Loaners from } \\
A_{R L^{b}} \text { initially }\end{array}$ & $\begin{array}{l}\text { Loaners from } \\
\text { ARL initially }\end{array}$ & - & - \\
\hline \multicolumn{8}{|c|}{ Other Radiometric Instruments } \\
\hline $\begin{array}{l}\text { All-weather cavity } \\
\text { pyrheliometer }\end{array}$ & Deluisi & Done & Done & Fall 1994 & - & - & 一 \\
\hline $\begin{array}{l}\text { Pyranometer for } 60-\mathrm{m} \\
\text { tower }\end{array}$ & DeLuisi & Done & Done & $12 / 93$ & - & - & - \\
\hline $\begin{array}{l}\text { Pyrgeometer for } 60-\mathrm{m} \\
\text { tower }\end{array}$ & Deluisi & Done & Done & $12 / 93$ & - & - & - \\
\hline $\begin{array}{l}\text { Solar spectral } \\
\text { radiometer }\end{array}$ & Deluisi & $\begin{array}{l}\text { Specifications } \\
\text { being written }\end{array}$ & $? ?$ & $? ?$ & - & 一 & - \\
\hline AERI & Griffin & Done & $\begin{array}{l}\text { Fall 1993; } \\
\text { lesting in } \\
\text { progress }\end{array}$ & $? ?$ & - & - & $\begin{array}{l}\text { Initial intake through } \\
\text { Experiment Center }\end{array}$ \\
\hline $\begin{array}{l}\text { Special IR brosdband } \\
\text { radiometer }\end{array}$ & - & - & $\begin{array}{l}\text { Unknown - } \\
\text { unmet } \\
\text { measurement }\end{array}$ & - & - & - & - \\
\hline
\end{tabular}


TABLE 8 (Cont.)

\begin{tabular}{|c|c|c|c|c|c|c|c|}
\hline Instrument & Mentor & Ordered & Delivered & $\begin{array}{c}\text { Central } \\
\text { Facility } \\
\text { Installation/ } \\
\text { Acceptance }\end{array}$ & $\begin{array}{l}\text { Extended } \\
\text { Facility } \\
\text { Installation/ } \\
\text { Acceptance }\end{array}$ & $\begin{array}{l}\text { Boundary } \\
\text { Facility } \\
\text { Installation/ } \\
\text { Acceptance }\end{array}$ & Comment \\
\hline $\begin{array}{l}\text { Multifilter radiometer } \\
\text { for upwelling at } 10 \mathrm{~m} \\
\text { and } 25 \mathrm{~m}\end{array}$ & Schmelzer & Done & $12 / 93$ & $12 / 93$ & - & - & - \\
\hline
\end{tabular}

- EML, Environmental Measurements Laboratory.

b ARL, Air Resources Laboratory. 


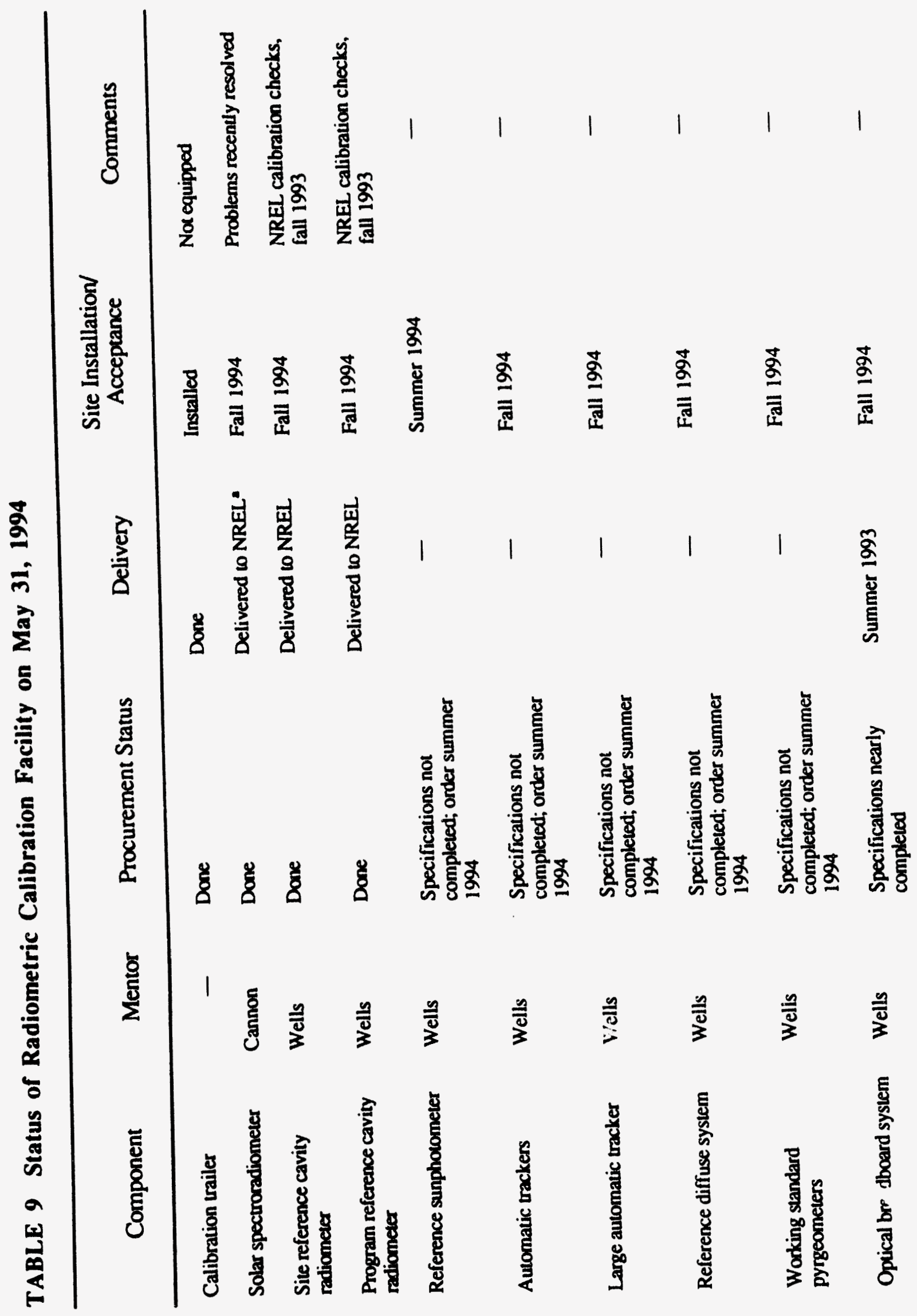


TABLE 9 (Cont.)

\begin{tabular}{llllll}
\hline Component & Mentor & Procurement Status & Delivery & $\begin{array}{c}\text { Site Installation } \\
\text { Acceptance }\end{array}$ & Comments \\
\hline NIST standard lamps & Wells & $\begin{array}{l}\text { Ordered } \\
\begin{array}{l}\text { Controlled current source } \\
\text { for lamps }\end{array}\end{array}$ & Wells & $\begin{array}{l}\text { Specifications being written; } \\
\text { order summer 1994 }\end{array}$ & Delivered 6/94 to NREL Fall 1994 \\
Reference blackbody & Wells & $\begin{array}{l}\text { Specifications not } \\
\text { completed; order summer } \\
1994\end{array}$ & Fall 1994 & Fall 1994 & Eppley standard blackbody \\
\hline
\end{tabular}

a NREL, National Renewable Energy Laboratory. 


\section{TABLE 10 Future Instruments}

\begin{tabular}{llll}
\hline Future Instruments (IDP) & IDP Investigator/Mentor & Procurement \\
\hline UV spectral radiometer & Harrison/? & No & Winter 1993? \\
Rotating shadowband spectrometer & Michalsky and Harrison/?? & No & Spring 1994? \\
SORTI & MurCray/Griffin & Summer 1994 & No \\
Net radiometric profiler & Whiteman/?? & No & Specifications being prepared \\
Cloud lidar & Goldsmith/Griffin & Not scheduled yet \\
Cloud radar & Widener (directed development) & Summer 1994 \\
Microwave water vapor profiler & McIntosh and Westwater/? & & Not scheduled yet \\
\hline
\end{tabular}

- Includes IDP instruments. 
some subset of the aerosol and calibration instrumentation, as indicated in Figure 3. Ozone sondes were originally included in the list of instruments planned for the SGP site, in anticipation of a need to correct radiation flux divergence measurements on the basis of vertical ozone profiles. A recent analysis of SPECTRE data indicated that the error in flux divergence (with and without ozone profiles) was less than $2 \%$, a figure smaller than the model calculation errors. The requirement for ozone profiles has been reexamined. The installation cost is moderate $(\$ 20,000)$, but the individual ozone sondes are expensive ( $\$ 700$ per sonde), and manpower needs are intensive. A newly identified potential need for ozone profiles concerns the overlap of the ozone and water vapor absorption bands in the region of the AERI data around a wave number of 1150. This overlap will require ozone profiles for analysis. This question has been evaluated by the Science Team and the EST. On the basis of all information, two sondes per month are now required to be launched at the central facility. The schedule for the two launches per month is still under discussion. Requirernents for an ozone system will be developed for procurement during this six-month period.

Of the ten extended facilities, the three with incomplete SIROS systems will be finished. Another four permanent sites will receive SIROS, and another five sites will receive SMOSes. If sufficient funds are available, six other facilities will be initiated and equipped as more SIROS, SMOS, and EBBR and/or EC systems become available.

When the turn-key boundary facilities have been completed (with BBSS and MWR permanently installed) and the AERI engineering problems have been resolved, an AERI will be available for use at the Vici boundary facility as well, but installation at Vici might be delayed until a system that operates without liquid nitrogen can be developed.

When all of these instruments are in place (as summarized in Tables 6 and 7), the first phase of instrumentation at the central and boundary facilities will be complete, leaving only the auxiliary and extended facilities to be completed.

Because of recent discussions with Science Team members involved in SCM boundary layer research, 915-MHz RASS systems might need to be deployed at three or more locations within $50 \mathrm{~km}$ of the central facility to better represent boundary layer conditions within the SGP CART site. This, in concept, would add a new boundary layer facility to the CART site. Siting requirements and new locations will need to be established. We hope to have such requirements established during this six-month period. 


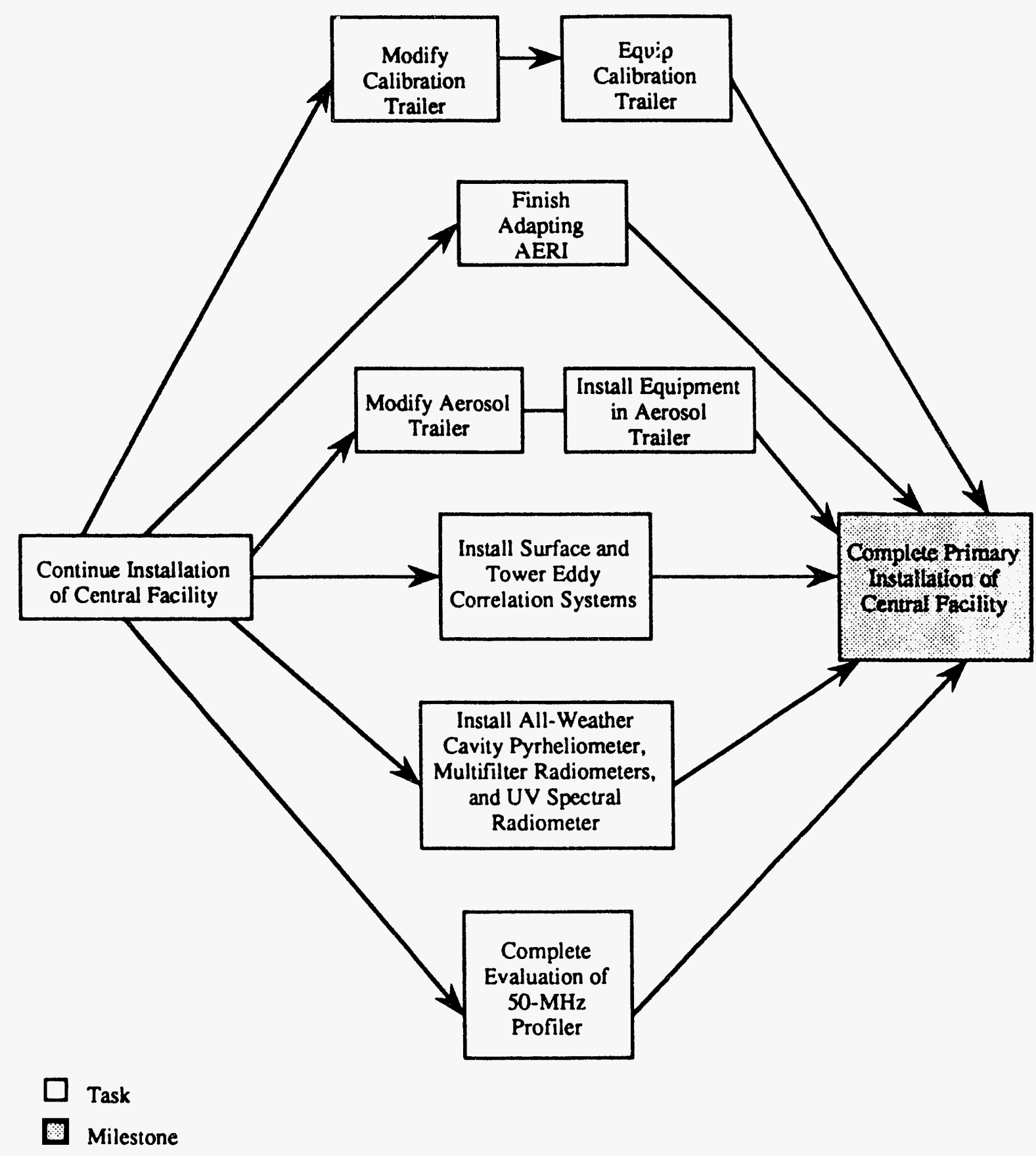

FIGURE 3 Site Development Activities to Install Central Facility 


\subsubsection{Data Intake Modules for the Site Data System}

Several of the installed instruments and all of the new instruments will require creation of software to transfer the data from the instrument platforms to the SDS. Transfer of data by coded switches from the extended facilities will also be required. Because the telephone lines cannot support data transfer from the boundary facilities, $\mathrm{T}-1$ lines will be installed at these locations.

\subsubsection{Measurements and External Data}

The Experiment Center will continue to prepare software to produce measurements from the available observations. The status of the measurements near the beginning of this six-month period is summarized in Table 4.

\subsubsection{Limiting Factors}

The most basic of limiting factors is the amount of resources available for continuing site development, expanding operations, and providing necessary support for the IT, the Data Management Team (DMT), and the EST. Shortfalls result in delays in implementation. Other significant limiting factors are the time lags inherent in the procurement process and the preinstallation calibration of radiometers.

All systems awaiting construction or installation go through a formal design review of structural and mechanical systems. For example, the aerosol intake stack for the aerosol trailer and the calibration platform deck have undergone such review. These reviews frequently identify deficiencies in plans and drawings related to engineering requirements, procurement details, and quality control. This activity was recently expanded to include large or complex IOPs like the Cloud Remote Sensing IOP, in an effort to integrate the staggering variety of IDP instrument support requirements for cost-effective implementation. Neither construction nor installation will begin until the design review process has been successfully completed.

The costs associated with BBSS launches (including both expendables and manpower) will be a burden on the operations budget until they are replaced by continuous, unmanned remote-sensing systems. These expenses are a strong constraint on the total number and frequency of launches, making it impossible to routinely provide all of the requested launches (eight per day at the central and boundary facilities) defined as the optimal sounding strategy for SCM requirements by the EST (Three Strategies for Soundings at the SGP CART Site by Bradley 
and Cederwall). A proposed site operations schedule that meets elements of both measurement strategies is outlined in Section 4.2.6.

Routine observations at boundary facilities will continue as outlined in the BBSS launch schedule outlined in Table 11. During the establishment of permanent boundary facilities, every effort will be made to minimize interruptions to that schedule. And as mentioned earlier, remote sensing of virtual temperature profiles at the boundary facilities will probably not occur during this six-month period, because NOAA is still testing and evaluating the RASSes under consideration for its $404-\mathrm{MHz}$ profilers.

\subsubsection{Schedule}

Changes in the schedule for site operations are driven primarily by the need to launch rawinsondes. Site operations staff and the EST have reached a compromise on the sonde launch schedule that becomes the target goal for these six months. Development and testing of the AERI and SORTI require other directed launches at the central facility, resulting in the compromise schedule outlined in Table 11. This routine schedule will be supplemented by four seasonal SCM IOPs annually, each lasting 21 consecutive days with eight rawinsonde launches per day. Our plan (Table 11) is to employ staggered shifts and a different launch schedule at the central facility and to conduct launches routinely only five days per week, to minimize these costs for the rest of this calendar year. The additional costs of GCIP (and VORTEX [Verification of the Origins of Rotation in Tornadoes Experiment] during May 1994) soundings have been supported by those organizations, allowing the current routine schedule at central and boundary facilities to be implemented in May 1994. The establishment of a 24-hr per day, 7-day work week at all facilities will be deferred until the resources are available.

\subsection{Routine Operations and Measurements Expected to be in Place by December 31, 1994}

\subsubsection{Observational Instruments and Systems}

The suite of instruments expected to be installed by December 31, 1994, is summarized in Tables 6 and 7. 
TABLE 11 Rawinsonde Launch Schedule, July 1-December 31, 1994 (Times in UTC) $^{\text {a }}$

Central Facility Boundary Facilities

Routine Operations, July 1-13, Monday-Friday

0600

0600

1200

1200

1500

1800

1800

2400

2100

SCM IOP, July 14-August 4, Monday-Sunday

0300

0300

0600

0600

0900

0900

1200

1200

1500

1500

1800

1800

2100

2100

2400

2400

GCIP IOP, August 5-25, Monday-Sunday

0600

0600

1200

1200

1500

1800

1800

2400

2100

2400

Routine Operations, August 25-October 13, Monday-Friday

0600

0600

1200

1200

1500

1800

1800

2400

2100

SCM, UAV IOP, October 14-November 3, Monday-Sundayb

0300

0300

0600

0900

0600

1200

0900

1200

1500

1500

1800

1800

2100

2100

2400

2400 
TABLE 11 (Cont.)

Central Facility

Boundary Facilities

Routine Operations, November 4-December 31, Monday-

Fridayb

0600

0600

1200

1200

1500

1800

1800

2400

2100

a UTC, universal time coordinates. Launch time is $\mathbf{3 0}$ min earlier; the stated time represents the approximate midpoint of the flight.

b A fourth boundary launch facility will be added before the October IOP.

\subsubsection{Measurements}

Table 12 provides a list of measurements, organized by type, derived from the SGP

CART site and external data.

TABLE 12 CART Measurements Expected to be in Place by December 31, 1994

\section{Radiation}

Point AERI downwelling IR radiance

Point MFRSR global, diffuse, direct solar narrowband irradiance

Point pyrgeometer downwelling global IR irradiance

Point pyrgeometer upwelling global IR irradiance

Point pyranometer downwelling global solar irradiance

Point pyranometer upwelling global solar irradiance

Central downwelling $10-\mu \mathrm{m}$ radiance

Reflected solar flux at top of atmosphere

Point IR $(9.5-$ to $11.5 \mu \mathrm{m})$ sky temperature

Satellite clear-sky reflectance

Satellite clear-sky-equivalent blackbody temperature

AVHRR radiances

High-resolution infrared radiation sounder radiances

VISSR atmospheric sounder radiances

Site 2-D grid of surface downwelling solar radiative flux

Site 2-D grid of surface upwelling solar radiative flux

Site 2-D grid of surface downwelling IR radiative flux

Site 2-D grid of surface upwelling IR radiative flux

Site average surface downwelling solar radiative flux

Site average surface upwelling solar radiative flux 


\section{TABLE 12 (Cont.)}

\section{Radiation (Cont.)}

Site average surface downwelling IR radiative flux

Site average surface upwelling IR radiative flux

\section{Temperature}

Central sonde vertical profile of temperature Boundary sonde vertical profile of temperature NWS sonde vertical profile of temperature Extended 3-D grid of temperature

Site vertical profile of slab-averaged temperature

Site vertical profile of slab-averaged advective temperature tendency

\section{Pressure}

Central sonde vertical profile of pressure

NWS sonde vertical profile of pressure

Extended 3-D grid of pressure

Extended 3-D grid of pressure surface heights

Site vertical profile of sonde-derived pressure gradient

Site vertical profile of RASS-derived pressure gradient

\section{Water Vapor}

Central inferred vertical profile of water vapor density

Central sonde vertical profile of relative humidity

Central sonde vertical profile of water vapor mixing ratio

NWS sonde vertical profile of relative humidity

Point MWR column-integrated "total precipitable" water vapor

Extended 3-D grid of water vapor mixing ratio (WVMR)

Site vertical profile of slab-averaged sonde WVMR

Site vertical profile of slab-averaged advective WVMR tendency

\section{Winds and Dynamics}

Central vertical profile of vertical wind components

Point sonde vertical profile of horizontal wind components

NWS sonde vertical profile of horizontal wind components

Two- and three-dimensional grids

Extended 2-D grid of surface horizontal wind components

Extended 3-D grid of horizontal wind components

Site vertical profile of slab-averaged horizontal wind components

Site vertical profile of slab divergence of horizontal wind

Site vertical profile of slab-averaged advective momentum tendency

Site vertical profile of vertical velocity

Site vertical profile of geostrophic wind components 
TABLE 12 (Cont.)

Trace Gases

Central surface ozone concentration

Aerosols

Central derived surface visibility

Central surface aerosol size distribution

Central surface aerosol absorption and scattering coefficient at $550 \mathrm{~nm}$

Central vertical profile of ceilometer relative aerosol backscatter

Cloud Bulk Morphology and Distribution

Central ceilometer cloud base height

Point satellite cloud top height

Central whole-sky image

Horizontal cloud distribution

Central fractional cloud cover

Cloud spacing

Cloud thickness

Site fractional cloud cover

Site cloud base height

Cloud top temperature (radiative)

Cloud base temperature (radiative)

NWS/USAF (U.S. Air Force) cloud fraction (by layer)

NWS/USAF cloud type (by layer)

NWS/USAF cloud base (by layer)

Cloud base height

\section{Cloud Microphysics and Precipitation}

Point MWR total cloud liquid water

Central vertical profile of phase of water

Point SMOS precipitation rate

Point NWS precipitation rate

Point Kansas Mesonet precipitation rate

Point Oklahoma Mesonet precipitation rate

Site 2-D grid of precipitation rate

Site total column cloud water

Cloud Optical Properties

Site satellite 2-D grid of 1-km-scale cloud albedo

Near-Surface Meteorology

Point SMOS near-surface temperature

Point flux station near-surface temperature (two levels)

Point NWS near-surface temperature

Point Oklahoma Mesonet near-surface temperature

Point Kansas Mesonet near-surface temperature 
TABLE 12 (Cont.)

Near-Surface Meteorology (Cont.)

Point SMOS near-surface pressure

Point flux station near-surface pressure

Point NWS near-surface pressure

Point Oklahoma Mesonet near-surface pressure

Point Kansas Mesonet near-surface pressure

Point SMOS near-surface relative humidity

Point flux station near-surface relative humidity

Point NWS near-surface relative humidity

Point Oklahoma Mesonet near-surface relative humidity

Point Kansas Mesonet near-surface relative humidity

Point SMOS near-surface horizontal wind components

Point flux station near-surface horizontal wind components

Point NWS near-surface horizontal wind components

Point Oklahoma Mesonet near-surface horizontal wind components

Point Kansas Mesonet near-surface horizontal wind components

Extended 2-D grid of near-surface temperature

Extended 2-D grid of near-surface pressure

Extended 2-D grid of near-surface water vapor mixing ratio

Site average near-surface temperature

Site average near-surface pressure

Site average near-surface water vapor mixing ratio

Site average near-surface horizontal wind components

Point-derived PBL (planetary boundary layer) depth

Central capping inversion depth

Site average PBL depth

\section{Surface Fluxes}

Point flux station surface sensible heat flux

Point flux station surface moisture flux

Point flux station surface momentum flux

Point flux station surface net radiation flux

EBBR surface latent heat flux

EBBR ground heat flux

Site 2-D grid of surface sensible heat flux

Site 2-D grid of surface moisture flux

Site 2-D grid of surface momentum flux

Site average surface sensible heat flux

Site average surface moisture flux

Site average surface momentum flux

\section{Surface Properties}

Point-derived broadband surface albedo

EBBR soil moisture

Gridded surface conditions

Site 2-D grid of surface roughness

Site 2-D grid of surface albedo

Site average surface albedo 
TABLE 12 (Cont.)

Surface Properties (Cont.)

Site average surface roughness

Site ground surface type

Site average surface WVMR

Site average ground temperature

\section{Quality Measurements}

Comparison of observed and calculated IR irradiance

Comparison of observed and calculated microwave brightness temperatures

Comparison of MWR and sonde precipitable water

Comparison of EBBR and SIROS net radiation 


\section{INTENSIVE OPERATIONS}

The base of the ARM CART Program is a suite of continuous observations, but a number of critical observations are either too expensive to be produced continuously at the desired frequency or require instrumentation that cannot be deployed continuously. In addition, some questions concerning data accuracy or representativeness (for either established instruments or prototypes) can be answered only with periods of more frequent observations. Acquiring these observations will require special efforts and arrangements by the SGP site staff; such events are categorized as IOPs, because they frequently include activities beyond the routine observations. The IOPs can be in support of the needs of the Science Team, QMEs, IDPs, campaigns, and even field tests of non-CART instruments. Table 13 lists IOPs that have occurred, are occurring, or are in the design stage.

The initial design of most special operations will be in the hands of the EST. Prototype procedures to facilitate the design, review, and implementation processes are outlined in a planning document for IOPs by Dickerson and Cederwall. Examples of such plans were included in the Site Scientific Mission Plan, January-July, 1994, "Winter SCM IOP Implementation Plan," Appendix A, and "Spring Integrated IOP Implementation Plan," Appendix B. Similar documents are being prepared by the Campaign Team leader to facilitate interagency collaborations and by the Operations Team leader to facilitate use of guest instruments. The SST will assist the EST in the generation of plans for special operations; will include the plans for newly approved QMEs, IOPs, and campaigns in the Site Scientific Mission Plan; and will assist in the execution of special operations. With the many-month lead time necessary to schedule research aircraft, it is important that design of special operations involving aircraft begin more than one year before the projected operation and be sufficiently complete to be included in collaborative proposals.

\subsection{Quality Measurement Experiments}

As part of the data quality assurance effort, our focus needs to go far beyond the simple calibration of instruments, to intercomparison of data streams and to evaluations of our ability to capture an accurate representation of the state of the atmosphere. The QMEs are experiments that address these problems and are designed and managed in a manner analogous to the experimental designs of the Science Team members. While QMEs can be proposed by anyone 
TABLE 13 Intensive Observation Periods

\begin{tabular}{|c|c|c|c|c|c|}
\hline Date & Nanie & $\begin{array}{c}\text { Science Team } \\
\text { Member }\end{array}$ & $\begin{array}{c}\text { EST } \\
\text { Contact }\end{array}$ & Description & Status \\
\hline $11 / 92$ & $\begin{array}{l}\text { Field Test of NCAR } \\
\text { Flux Profiler }\end{array}$ & D. Parsons (NCAR) & R. Cederwall & $\begin{array}{l}\text { Enhanced soundings at the central } \\
\text { facility and profiler site were made } \\
11 / 10-11 / 19 ; \text { boundary layer flights } \\
\text { were also conducted on a few days. }\end{array}$ & $\begin{array}{l}\text { Completed; data available } \\
\text { summer } 1993 \text {. }\end{array}$ \\
\hline $4 / 93$ & AERI Field Test & H. Revercomb (UW) & J. Liljegren & $\begin{array}{l}\text { Enhanced soundings at the central } \\
\text { facility were requested during the field } \\
\text { acceptance test of the AERI } \\
\text { instrument. }\end{array}$ & Completed 4/29/93. \\
\hline $\begin{array}{l}5 / 93 \\
6 / 93\end{array}$ & $\begin{array}{l}\text { Using the Global } \\
\text { Positioning System } \\
\text { (GPS) for the } \\
\text { Measurement of } \\
\text { Atmospheric Water } \\
\text { Vapor }\end{array}$ & $\begin{array}{l}\text { Collaborative } \\
\text { (UNAVCO and NCSU) }\end{array}$ & J. Liljegren & $\begin{array}{l}\text { The purpose was to test the } \\
\text { investigators' lechnique for inferring } \\
\text { lotal precipitable water vapor in the } \\
\text { atmosphere column by using GPS } \\
\text { signals. }\end{array}$ & $\begin{array}{l}\text { Completed 6/8/93; data } \\
\text { available. }\end{array}$ \\
\hline $6 / 93$ & $\begin{array}{l}\text { Warm Seasun Data } \\
\text { Assimilation and } \\
\text { Integrated Sounding } \\
\text { System (ISS) Test }\end{array}$ & D. Parsons (NCAR) & R. Cederwall & $\begin{array}{l}\text { This was an enhanced sampling (in } \\
\text { ime and space) of the SGP domain } \\
\text { for a 10-day period with profilers and } \\
\text { sondes. The primary goals of the IOP } \\
\text { were (1) to study the performance of } \\
\text { four-dimensional data assimilation } \\
\text { (FDDA) under thermodynamic } \\
\text { conditions typical of the continental } \\
\text { warm season and (2) to evaluate the } \\
\text { estimates of divergence and vorticity } \\
\text { from the prototype NCAR ISS with } \\
\text { interferometric techniques, the triangle } \\
\text { of three } 915-\mathrm{MHz} \text { profilers, and the } \\
\text { results of FDDA. }\end{array}$ & $\begin{array}{l}\text { Completed; all data } \\
\text { available at the } \\
\text { Experiment Center except } \\
\text { for FDDA, which will be } \\
\text { available upon request at } \\
\text { NCAR by the end of } \\
1994 \text {. }\end{array}$ \\
\hline
\end{tabular}


TABLE 13 (Cont.)

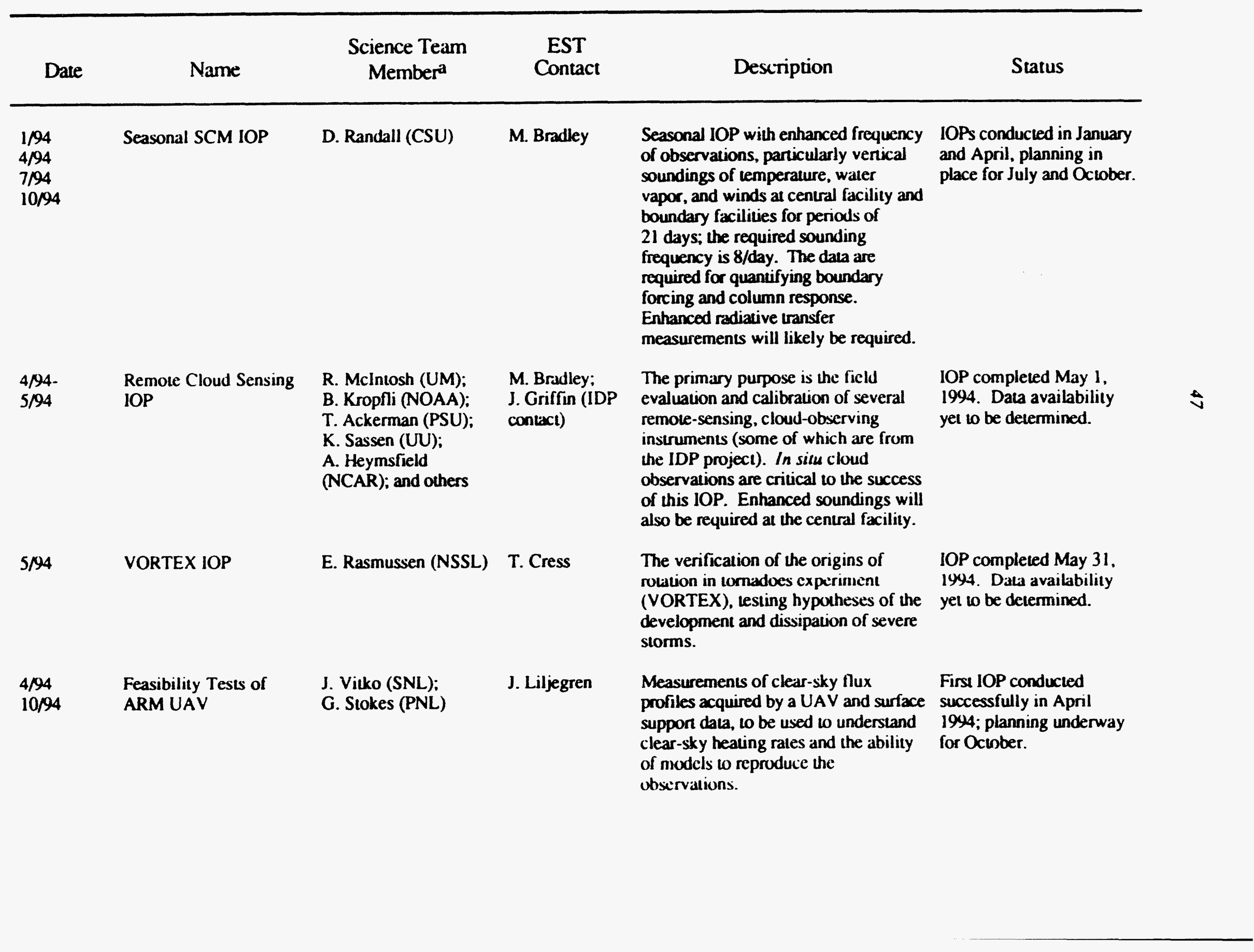


TABLE 13 (Cont.)

\begin{tabular}{|c|c|c|c|c|c|}
\hline Date & Name & $\begin{array}{c}\text { Science. Team } \\
\text { Mernber }^{\mathrm{a}}\end{array}$ & $\begin{array}{c}\text { EST } \\
\text { Contact }\end{array}$ & Description & Status \\
\hline $\begin{array}{l}4 / 95- \\
5 / 95\end{array}$ & $\begin{array}{l}\text { Simultaneous Ground- } \\
\text { Based, Airtome, and } \\
\text { Satellite-Borne } \\
\text { Micruwave Radiometric } \\
\text { and In Silu Observations } \\
\text { of Cloud Optical } \\
\text { Properties and Surface } \\
\text { Emissivities }\end{array}$ & $\begin{array}{l}\text { W. Wiscombe (NASA- } \\
\text { GSFC); E. Westwater } \\
\text { (NOAA-WPL) }\end{array}$ & J. Liljegren & $\begin{array}{l}\text { Observations of cloud optical } \\
\text { properties will be obtained over the } \\
\text { CART site simultaneously from } \\
\text { ground-ba:sed, in situ, and satellite- } \\
\text { bome sensors; spatial variability of } \\
\text { surface emissivities will be assessed } \\
\text { to auempt retrieval of total } \\
\text { precipitable water and cloud liquid } \\
\text { water from the special sensor } \\
\text { microwave imager. }\end{array}$ & $\begin{array}{l}\text { Proposal distributed ( } 10 \\
\text { IRF); initial planning } \\
\text { discussions between } \\
\text { Wiscombe andi l.. Fedor at } \\
\text { NOAA; proposai for } \\
\text { NOAA P-3 aircraft for } \\
3 \mathrm{hr} \text { submitted by } \\
\text { Wiscombe and Schneider } \\
\text { in collaboration with } \\
\text { VORTEX. }\end{array}$ \\
\hline
\end{tabular}

- Affiliations: CSU, Colorado State University; GSFC, Goddard Space Flight Center; NASA, National Aeronautics and Space Administration; NCAR, National Center for Atmospheric Research; NCSU, North Carolina State University; NOAA, National Oceanic and Aumospheric Administration; NSSL, National Severe Storms Laboratory; PNL, Pacific Northwest Laboratory; PSU, Pennsylvania State University; SNL, Sandia National Laboratories: UM, University of Massachusseus; UNA VCO, University NAVSTAR Consortium; UU, University of Utah; UW, University of Wisconsin; VORTEX, the verification of the origins of rotation in tomadoes experiment; WPL, Wave Propagation Laboratory. 
within the ARM Program, they constitute a special joint responsibility for the EST and the SST. Not all QMEs require IOPs or increased data taking. The following is an example:

QME Name:

Science Team Member: (STM Contact)

EST Contact:

Status:

Brief Description:
Comparison of MWR and Sonde Water Vapor Profiles

E. Westwater

J. Liljegren/N. Miller

Ongoing; executed automatically at the Experiment Center

The purpose of the QME is twofold: (1) Use soundings from the BBSS to drive a radiation transfer model (from Atmospheric and Environmental Research, Inc. [AER]) and compute the microwave brightness temperatures that the MWR should see, then compare the calculated values to the actual brightness temperatures observed by the MWR. (The relationship between the computed and observed values is the "tuning function" needed to account for shortcomings in the model. The retrieval coefficients supplied by AER and used by the MWR for deriving the precipitable vapor and liquid water path from the brightness temperatures were based on this model. Thus, to use the retrievals coefficients requires a transformation from actual space to model space.) (2) Compare the precipitable vapor computed along the sonde trajectory with the equivalent quantity derived from the averaged MWR brightness temperatures by using the AER-supplied retrieval coefficients.

The QMEs that are either underway, in preparation, or under consideration include the following:

- Comparison of spectral radiances observed by the AERI and computed by the LBLRTM. This QME analyzes the residual differences and uses temperature and moisture profiles from the central facility as input. The goal is to improve the modeling of the surface spectral radiances.

- Comparison of cloud base observation data derived from the Scripps WSI, the Belfort ceilometer, the Spinhirne micropulse lidar ceilometer, and any cloud radars deployed at the central facility for IOPs. This QME is under consideration; we are awaiting installations and IOPs including cloud radars.

- Comparison of broadband radiative surface fluxes, both between instruments measuring the same quantity and calculated from combinations of observations. 
This effort is currently in draft form and will be developed further and executed when the new SIROS is installed at the central facility (in preparation).

- Comparison of thermodynamic profiles derived from the BBSS and the RASS profilers, with near-surface values from the SMOS and the 60-m tower instruments. This QME is under consideration; we are awaiting installation of the $50-\mathrm{MHz}$ profiler.

- Comparison of wind profiles derived from the BBSS and the profilers. This QME is under consideration; we are awaiting installation of the $50-\mathrm{MHz}$ profiler.

- Comparison of the fluxes derived from the EBBR and EC systems. This QME is under consideration; we are awaiting installation of the EC system at the central facility.

The results of these and other QMEs will have both short- and long-term effects on the ARM data stream and on site management, including advisories to the Science Team concerning data quality, modifications in data acquisition strategies, and reassessments of measurement algorithms. The most important and unique of the instrument comparisons will be distributed as internal ARM reports and submitted for publication in appropriate journals.

\subsection{Supplement to Continuous Observations}

Six of the IOPs listed in Table 13 are primarily for the purpose of testing instrument systems intended for possible ARM deployment, but four of these IOPs will also produce supplemental data of use to the Science Team at large (the Field Test of NCAR Flux Profiler, the Warm Season Data Assimilation and Integrated Sounding System Test, the Remote Cloud Sensing IOP, and the Feasibility Tests of ARM UAV). Other IOPs listed in Table 13 will specifically address unfilled observational needs of the SCM and DA groups: the WiscombeWestwater cloud observations and the Seasonal SCM IOP. The Wiscombe-Westwater cloud observations have been postponed until the spring of 1995, because of difficulties involved in arranging for appropriate aircraft support. The Seasonal SCM IOP will run again in July and continue in October. The only critical dependency in site development for the Seasonal SCM IOPs is the initiation of a fourth boundary facility before the October start date. 


\subsection{Support for the Instrument Development Programs, Guest Instruments, and Campaigns}

The SGP CART site is an ideal location for rigorous field tests of new observational systems and has been designed to support these activities with a minimum of disruption to the continuous observations. Six of the IOPs in Table 13 were designed to support various instrument development activities. The field tests of the NCAR flux profiler (November 1992 and June 1993) are continuing efforts in the development of an instrument that will remotely and continuously measure near-surface momentum and virtual temperature fluxes. The AERI (April 1993) should be capable of routine detection of infrared radiances with high spectral resolution and accuracy and will be essential to experiments on the effects of greenhouse gases, clouds, and fine particles on atmospheric transmission, absorption, and emission. More AERIs are scheduled for later deployment at the SGP boundary facilities, where they will be used to infer vertical profiles of temperature and humidity below the cloud base. The global positioning system (GPS) is an example of use of a problem (noise in the data stream of the system) in an attempt to produce a continuous, low-cost measurement (total water vapor in the intervening atmosphere, and possibly profiles of water vapor) that would be of value to the ARM Program. The GPS effort was not funded by ARM, but it was hosted by the site as a guest instrument. The SGP CART site is also a logistically friendly base for early tests of the ARM UAV (April and October 1994), a platform that figures prominently in plans for future oceanic CART sites. The ARM UAV program is a self-standing sister program of ARM CART. The ARM UAV effort is a campaign that will occur simultaneously with the fall SCM IOPs. The Remote Cloud Sensing IOP (April-May 1994) was a critical step toward building a capability to remotely and continuously observe both cloud distribution and microstructure, which are currently unfilled SGP observational needs.

\subsection{Campaign Planning}

Table 14 summarizes potential campaigns and cooperative projects that have been called to our attention. Plans for these activities are in various stages of development, and the topics are listed briefly here to generate further discussion. Inclusion in this list does not imply any endorsement of these activities by the ARM Program, except for the GVaP (GEWEX Water Vapor Project) as the Department of Energy's contribution to GEWEX.

Except for some special hydrologic measurements, the GEWEX/GCIP/GIST (GEWEX Integrated System Test) observations will be limited to currently operational observation 
networks and the SGP data. The GIST participants have expressed a strong interest in scheduling their field work simultaneously with our spring and summer SCM IOPs.

TABLE 14 Collaborative Campaigns and Activities under Discussion

\begin{tabular}{|c|c|c|}
\hline Title & Proponent/Contact ${ }^{\mathrm{a}}$ & Projected Date \\
\hline Flux Divergence & J. Vitko & Spring 1994 \\
\hline Ultraviolet-B Intercomparison & A. Thompson (NIST, DOA) & Spring 1994 \\
\hline GEWEX ISLSCP/GCIPb & P. Sellers & \\
\hline GIST & & Spring, summer 1994 \\
\hline Land Surface Studies & & $?$ \\
\hline VORTEX & E. Rasmussen (NSSL) & Spring 1994, 1995 \\
\hline $\begin{array}{c}\text { Project Halo: Annular Solar } \\
\text { Eclipse Observations }\end{array}$ & G. Stokes & May 10, 1994 \\
\hline BOREAS (Boreal Ecosystems Atmosphere Study) & W. Pennell & July 19-August 8, 1994 \\
\hline GVaP (water vapor profile intercomparison) & H. Melfi & Spring 1995 \\
\hline Cooperative Multiscale Experiment & W. Cotton (CSU) & Spring, summer 1995 \\
\hline GCSS & M. Moncrieff & $?$ \\
\hline $\begin{array}{l}\text { CASES (Cooperative Atmosphere-Surface } \\
\text { Exchange Site, boundary layer and } \\
\text { hydrology facility) }\end{array}$ & W. Blumen (CU) & $?$ \\
\hline Gulf Moisture & W. Pennell & $?$ \\
\hline
\end{tabular}

a Affiliations: CSU, Colorado State University; CU, Colorado University; DOA, Department of Agriculture; NIST, National Institute of Standards and Technology; NSSL, National Severe Storms Laboratory.

b ISLSCP/GCIP, International Satellite Land-Surface Climatology Project/GEWEX Continental-Scale International Project. 


\section{DISTRIBUTION OF DATA}

As mentioned in Section 3, the EST is in the process of distilling the measurements required by the Science Team proposals in terms of the four GMS categories. In addition to that activity, the Experiment Center has begun to track data requests, particularly who has requested data and how much of the request is being delivered in a weekly time period. This new section of the Site Scientific Mission Plan attempts to integrate these two activities by grouping the users of the data into IRF, SCM, DA, HD, IDP, and miscellaneous categories. The first four represent the GMS categories. The IDP category addresses IDP mentors who have requested data in support of their activities. The last category includes requests for data by the instrument mentors, as well as data requests by individuals either associated within the ARM infrastructure and outside the ARM Program. Table 15 summarizes the particulars of the data being delivered to users. Table 15 reflects the EOP (from which the EST determines what data streams are required), the number of data platforms required by the EOP (data platforms include both observations and measurements obtained by an instrument with more than one sensor or providing more than one data stream, or by more than one instrument), the number of platforms the SGP CART site has or will have in the field, and a percent based on the average of the weekly number of platforms and the number of platforms available being delivered from March 7, 1994, through May 15, 1994.

Table 15 is not complete. It is based only on the information that had been officially logged and was available at the time of this report. Most of the data being requested are received from the SGP CART site or external data sources and then repackaged for weekly distribution to the individual users. In some cases, the user can log into the Experiment Center and extract data (by anonymous File Transfer Protocol, FTP). It is more difficult to track what the data user is actually receiving from the Experiment Center. The information presented in Table 15 indicates that $60 \%$ of the IRF users, $44.4 \%$ of the SCM users, $70 \%$ of the DA users, $14.3 \%$ of the HD users, $18.2 \%$ of the IDP users, and $44.4 \%$ of the miscellaneous users have been receiving some level of data for the period specified. Overall, $40 \%$ of the Science Team members are receiving some level of data, and $43.3 \%$ of the users over all categories are receiving data.

The information indicates that the IRF category has the largest number of users receiving data. This is because the central facility instrumentation addresses nearly all of the platform requirements of the IRF, and the central facility is nearly complete. More and more platforms will be available as boundary facilities are more fully developed and the number of extended facilities increases. 
TABLE 15 Statistics of Delivery of Data to Users

\begin{tabular}{|c|c|c|c|c|}
\hline Data Users ${ }^{a}$ & $\begin{array}{l}\text { EOP } \\
\text { Number }\end{array}$ & $\begin{array}{l}\text { Platforms } \\
\text { Required }\end{array}$ & $\begin{array}{l}\text { Platforms } \\
\text { Available }\end{array}$ & $\begin{array}{l}\text { Average \% } \\
\text { Available } \\
\text { Platforms } \\
\text { Delivered } \\
3 / 7-5 / 15,1994\end{array}$ \\
\hline
\end{tabular}

Instantaneous Radiative Flux Data Users

$\begin{array}{lrr}\text { Anderson } & 59 & 16 \\ \text { Byrne } & 19 & 18 \\ \text { Clough } & 16 & 20 \\ \text { Curry } & - & 21 \\ \text { Ellingson } & 13 & 21 \\ \text { Gautier/Lovejoy } & 8 & - \\ \text { Gray } & - & 2 \\ \text { Grund } & - & 21 \\ \text { Harrison/Michalsky } & 6 & - \\ \text { Lacis/Del Genio } & 18 & - \\ \text { Landsfeld } & 8 & - \\ \text { Melfi } & - & 55 \\ \text { Penner } & - & - \\ \text { Rocken } & - & - \\ \text { Smith } & 55 & - \\ \text { Stamnes } & 27 & - \\ \text { Stephens/Gabriel } & - & \\ \text { Varanasi } & - & \\ \text { Wang } & 10 & \\ \text { Wiscombe } & 17 & \end{array}$

16

18

20

21

21

$-$

2

20

21

$-$

$-$

55

27

$-$

54

Single-Column Model Data Users

Baer
Cess
Ghan (\#1)
Kao (\#2)
Randall
Somerville
Schwartz
Stull
Walcek

61

17

19

19
17

17

$\overline{1}$

52.4

$$
-
$$

Anonymous ${ }^{b}$

69.7

61.8

$-$

$-$

72.1

59.8

-

76.1

31.2

68.0

$-$

22

2

27

$-$

$-$

Data Assimilation Research Data Users

$\begin{array}{lrrr}\text { Ackerman (PSU) } & 58 & 38 & 27 \\ \text { Bergstrom } & 54 & 15 & 14 \\ \text { Coulter } & 48 & 23 & 22 \\ \text { Doran } & 45 & 21 & 0 \\ \text { Kinne } & 54 & 15 & 14 \\ \text { Louis } & - & - & -\end{array}$

48.6 Anonymous ${ }^{b}$ 72.2 Anonymous $b$ Anonymous $b$ 
TABLE 15 (Cont.)

\begin{tabular}{|c|c|c|c|c|}
\hline Data Users ${ }^{a}$ & $\begin{array}{l}\text { EOP } \\
\text { Number }\end{array}$ & $\begin{array}{l}\text { Platforms } \\
\text { Required }\end{array}$ & $\begin{array}{l}\text { Platforms } \\
\text { Available }\end{array}$ & $\begin{array}{l}\text { Average \% } \\
\text { Available } \\
\text { Platforms } \\
\text { Delivered } \\
3 / 7-5 / 15,1994\end{array}$ \\
\hline
\end{tabular}

Data Assimilation Research Data Users (Cont.)

$\begin{array}{lrrrr}\text { Mace (PSU) } & 47 & 5 & 5 & 32.0 \\ \text { Parsons (NCAR) } & 46 & 4 & 4 & 0 \\ \text { Raman } & 51 & 22 & 21 & 58.6 \\ \text { Toon/Westphal } & - & - & - & -\end{array}$

Hierarchical Diagnosis Research Data Users

Bradley

Cotton (\#1)

Cotton (\#2)

Del Genio

Gal-Chen/Chen

(CIMMS/OU)

Ghan (\#2)

Heymsfield

Kegelmeyer

Kogan (CIMMS/OU)

Kogan/Lilly/Kogan

(CIMMS/OU)

Kropfli

Krueger

Lamb/Schneider

(CIMMS/OU)

Lamb/Stensrud

(CIMMS/OU)

Mitchell

Morrissey/Postawko

(CIMMS/OU)

Ramanathan

Stensrud/Brooks

(CIMMS/OU)

Webster

$\mathrm{Xu} / \mathrm{Dong}$ (CIMMS/OU)

Young

Instrument Development Program Data Users

Eberhard

Goldsmith

McIntosh

-
$\overline{-}$
$\overline{18}$
-
-
$\overline{-}$
-
-

$-$

$-$

20

$-$

$-$

$-$

$-$

$-$

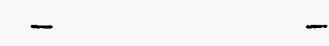

$\overline{44}$

2

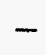

$-$

$-$

12

-

$-$

$-$
0

8.6

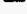


TABLE 15 (Cont.)

\begin{tabular}{|c|c|c|c|c|}
\hline Data Users ${ }^{a}$ & $\begin{array}{l}\text { EOP } \\
\text { Number }\end{array}$ & $\begin{array}{l}\text { Platforms } \\
\text { Required }\end{array}$ & $\begin{array}{l}\text { Platforms } \\
\text { Available }\end{array}$ & $\begin{array}{l}\text { Average \% } \\
\text { Available } \\
\text { Platforms } \\
\text { Delivered } \\
3 / 7-5 / 15,1994\end{array}$ \\
\hline \multicolumn{5}{|c|}{ Instrument Development Program Data Users (Cont.) } \\
\hline $\begin{array}{l}\text { Murcray } \\
\text { Platt } \\
\text { Revercomb/Murcray } \\
\text { Sassen } \\
\text { Spinhirne } \\
\text { Valero } \\
\text { Westwater/Gage } \\
\text { Whiteman }\end{array}$ & $\begin{array}{l}\overline{-} \\
\overline{11} \\
\overline{-} \\
\overline{30} \\
-\end{array}$ & $\begin{array}{r}- \\
\overline{2} \\
- \\
- \\
\overline{4} \\
-\end{array}$ & $\begin{array}{r}- \\
\overline{1} \\
- \\
\overline{-} \\
13 \\
-\end{array}$ & $\begin{array}{r}- \\
60 . \overline{1} \\
- \\
- \\
\overline{-} \\
28 . \overline{-}\end{array}$ \\
\hline \multicolumn{5}{|c|}{ Miscellaneous Data Users } \\
\hline $\begin{array}{l}\text { Arbarbanel } \\
\text { DeLuisi } \\
\text { Knuteson } \\
\text { Larsen } \\
\text { Minnis } \\
\text { Sandberg } \\
\text { Schwartz } \\
\text { Stokes } \\
\text { Welch/Feind }\end{array}$ & $\begin{array}{r}- \\
14 \\
11 \\
27 \\
60 \\
14 \\
- \\
- \\
-\end{array}$ & $\begin{array}{r}- \\
2 \\
22 \\
27 \\
5 \\
2 \\
- \\
- \\
-\end{array}$ & $\begin{array}{r}- \\
0 \\
22 \\
24 \\
0 \\
0 \\
- \\
- \\
-\end{array}$ & $\begin{array}{l}- \\
\text { Anonymous } \\
69.5 \\
69.0 \\
0 \\
\text { Anonymous } \\
\text { - } \\
- \\
-\end{array}$ \\
\hline
\end{tabular}

a Affiliations of users: CIMMS, Cooperative Institute for Mesoscale Meteorological Studies; NCAR, National Center for Atmospheric Rescarch; OU, Oklahoma University; PSU, Pennsylvania State University.

b Data are obtained by the requestor by anonymous FTP. The number of data platforms delivered is not known by the Experiment Center staff or the DMT. 


\section{LOOKING AHEAD}

As indicated in earlier sections, substantial progress has been made on the development of the SGP CART site, and this progress will be further consolidated during the upcoming six months. Thus, by late 1994, the observational capabilities of the central and boundary facilities will be mostly complete, and the ability of the SDS to handle the resulting data streams will be substantially enhanced. These developments will ensure that the SGP CART site's 1995 support of the GMS needs for SCM, DA, and HD research by Science Team members will be substantially greater than in previous years. The counterpart support for quantifying the SGP IRF, which was initiated earlier in the CART site development, will also be at a high level in 1995. This maturing of the site and enhancement of its data streams and their accessibility should greatly facilitate the Science Team's use of the SGP CART data in an interactive, nearreal-time mode during 1995. One of the most unique potentials of the ARM Program will thus begin to be realized.

During 1995, the SGP CART observational capabilities will probably be further enhanced as a result of ongoing interactions between ARM and other federally funded research programs having an interest in the Southern Great Plains. These interactions particularly involve the GCIP component of GEWEX and have already resulted in the formation of a joint ARMGCIP Working Group (on which ARM is represented by Bob Ellingson, Peter Lamb, and David Randall) and GCIP's agreement to fund additional SGP CART rawinsonde observations during the next six months. This GCIP funding of additional rawinsonde soundings is expected to continue (and perhaps be enhanced) during 1995. In addition, the GCIP component of NOAA's Climate and Global Change Program has agreed to consider a proposal from the SST to develop a comprehensive soil moisture monitoring capability for much of the total SGP CART domain that would fulfill the needs of both ARM and GCIP. If this proposal is funded, approximately one-third of the planned operational network will be installed and become operational in 1995, with completion in 1996. This potentially important enhancement of the SGP CART observational capabilities would strongly complement the ARM extended facilities, which are primarily intended to facilitate the spatial integration of the surface heat, moisture, and momentum exchanges across the CART domain.

The aforementioned ARM-GCIP Working Group is expected to be particularly concerned with helping to formulate observational strategies for the SGP CART for 1995. Beyond that, the Working Group will benefit both programs by fostering the most cost-effective and efficient operations possible. Somewhat less formal interactions with the VORTEX program, which were 
initiated during the last six months, are expected to continue in 1995. These interactions led to funding by VORTEX of an enhancement of the spring 1994 SGP CART rawinsonde observations. Similar synergism anticipated for the spring 1995 will probably include joint aircraft observations. The integration of ARM UAV operations into the SGP CART scientific mission was successfully initiated in April 1994. It will be further developed in September 1994 and is expected to continue as an UAV IOP in 1995. Future UAV operations will be supported by climatological analyses of SGP historical cloud and tropospheric wind data. The ARM-GCIP interactions discussed above are also expected to lead to beneficial exchanges with the BOREAS component of ISLSCP in 1995.

The continued ramping up of SGP CART site operations during the remainder of 1994 and 1995 is thus expected to result in a mature pursuit of the scientific mission for this ARM locale by late 1995 . 

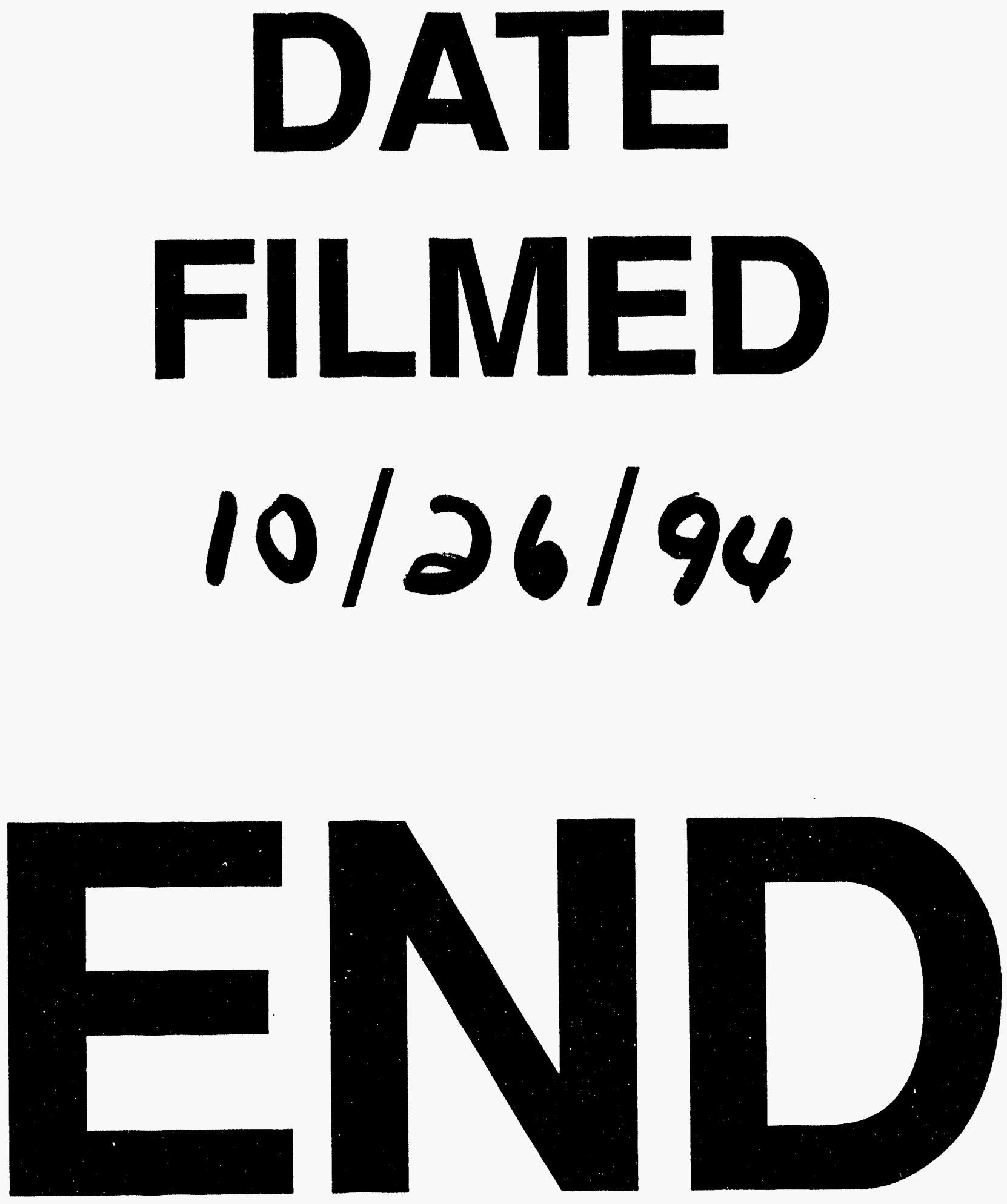


$$
\text { - }
$$

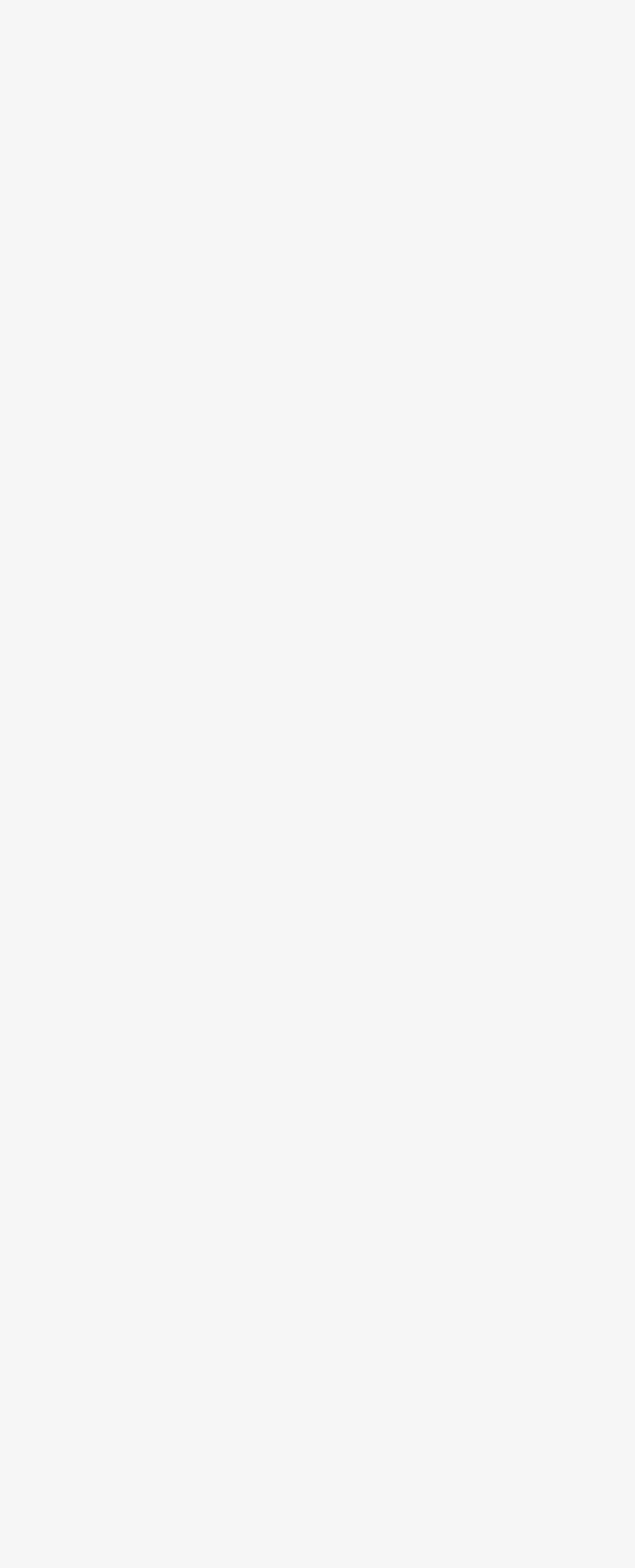

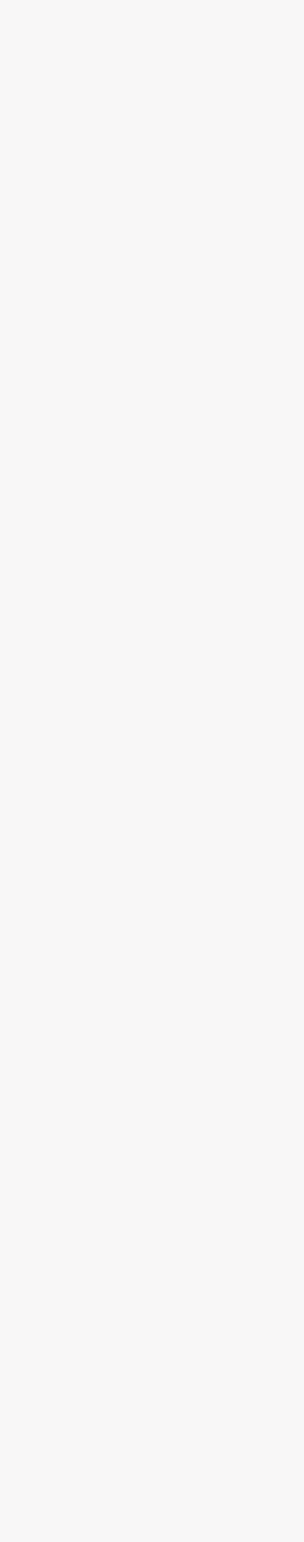

